\title{
A Necessary Social Evil: The Indispensability of the Shareholder Value Corporation
}

\author{
Marc T. Moore*
}

This symposium article critically evaluates the developing Post-Shareholder-Value (PSV) paradigm in corporate governance scholarship and practice with particular reference to Professor Colin Mayer's influential theory of the corporation as a unique, long-term "commitment device." The article's positive claim is that, while evolving PSV institutional mechanisms such as benefit corporations and dual-class share structures are generally encouraging from a social perspective, there is cause for skepticism about their capacity to become anything more than a niche or peripheral feature of the U.S. public corporations landscape. This is because such measures, despite their apparent reformist potential, are still ultimately quasi-contractual and thus essentially voluntary in nature, meaning that they are unlikely to be adopted in a public corporations context except in extraordinary instances. This Article's normative claim is that, while in many respects the orthodox shareholderoriented corporate governance framework may be a social evil, it is nonetheless a necessary evil, which U.S. worker-savers implicitly tolerate as the effective social price for sustaining a system of nonoccupational income provision outside of direct state control. Accordingly, pending fundamental reform of the broader social-institutional context to the shareholder-oriented corporation, the key features of the evolving PSV

\footnotetext{
* Reader in Corporate Law, Director of the Centre for Corporate and Commercial Law (3CL), and Fellow of Murray Edwards College, University of Cambridge, UK (mtm48@cam.ac.uk). This article was initially written for the 8th annual Symposium of the Adolf A. Berle, Jr. Center on Corporations, Law \& Society, "Benefit Corporations and the Firm Commitment Universe," held at the Seattle University School of Law on June 27-28, 2016. I am thankful to the Berle Center and Professor Charles O'Kelley for inviting me to participate in this symposium, and to fellow participants for their insightful and helpful comments on my presentation. Earlier versions of this article were presented at the University of Bristol, the University of York, and the University of Southampton in the UK. I am grateful for comments received from participants at all of these events. I am further indebted to the Leverhulme Trust for funding the time involved in the researching and writing of this article. The opinions expressed and also any outstanding errors are those of the author alone.
} 
governance model should remain quasi-contractual as opposed to being placed on any sort of mandatory regulatory footing.

\section{CONTENTS}

INTRODUCTION 428

I. Firm Commitment And The Post-Shareholder-VAlue

THOUGHT PARADIGM. 434

A. Mayer's Firm Commitment Thesis

B. The Broader Post-Shareholder-Value Thought Paradigm

II. THE POST-SHAREHOLDER-VALUE POLICY PARADIGM. 442

A. The Benefit Corporation Framework 443

B. Practical Limitations Of The Benefit Corporation Framework ... 447

C. Broad Judicial Legitimation Of Managerial Hostile Takeover

Defenses 450

D. Enhanced Use Of Dual-Class Voting Structures 451

III. SHOUld The PSV CORPORATE GOVERNANCE MODEL Be PuT ON A FIRMER REGULATORY FOOTING? 453

A. The "Market Failure" Rationale For Mandatory Regulatory

Imposition Of PSV Corporate Governance Principles 453

B. The (Neglected) Social-Distributive Dimension Of Corporate

Equity Markets 455

C. The Shareholder Primacy Norm As A Socially Essential Income-

Stabilization Mechanism. 458

D. Shareholder Primacy As The Effective Social "Price" Of

Sustaining A Capital-Market-Based Pensions System 461

CONCLUSION

\section{INTRODUCTION}

Scholars of the modern public corporation mutually agree that their subject of study is a truly remarkable institution. Far less commonly agreed upon, though, is precisely why this is so. Over the past four decades, social-scientific analysis of business corporations-at least in the English-speaking world - has been dominated in large part by reductionist theories inspired by neoclassical economics, which essentially seek to break the corporation (or "firm") down to its component human parts. ${ }^{1}$

1. See, e.g., Armen A. Alchian \& Harold Demsetz, Production, Information Costs, and Economic Organization, 62 AM. ECON. REV. 777 (1972); Eugene F. Fama, Agency Problems and the Theory of 
From this general viewpoint, the purported significance of the corporation is typically perceived as residing in its capacity to enable corporate participants (as notional "contractors") to economize on the transaction costs involved in both financing and organizing complex production projects on a collective scale. $^{2}$

Accordingly, various legal features of the corporation-including limited liability, ${ }^{3}$ separate legal personality, ${ }^{4}$ and centralized board management ${ }^{5}$ - have on different occasions been lauded as its key organizational characteristic. At the same time, debate over the rightful distribution of decision-making influence within the corporate structure has steadily burned on, whereby the relative advantages and disadvantages of allocating legal governance powers to directors versus shareholders have been variously chewed over. ${ }^{6}$ However, while the instrumental question as to the most effective legal "means" of corporate governance has been a topic of fervent disagreement, the corresponding issue of the ultimate social "end" to which these efforts should be driving towards has, until fairly recently, been a conspicuous point of acquiescence amongst otherwise diametrically opposed observers. ${ }^{7}$

the Firm, 88 J. POL. ECON. 288 (1980); Eugene F. Fama \& Michael C. Jensen, Separation of Ownership and Control, 26 J.L. \& ECON. 301 (1983); Michael C. Jensen \& William H. Meckling, Theory of the Firm: Managerial Behavior, Agency Costs and Ownership Structure, 3 J. FIn. ECON. 305 (1976).

2. See, e.g., Stephen M. Bainbridge, The New Corporate Governance in Theory and Practice (2008) [hereinafter Bainbridge, THE NeW Corporate Governance]; BRian R. ChEFFins, COMPANY LAW: THEORY, STRUCTURE AND OPERATION (1997); Frank H. EASTERBRooK \& Daniel R. Fischel, The Economic Structure of Corporate Law (1991) [hereinafter EASTERBROOK \& FisCHEL, CORPORATE LAW]; R. KRAAKMAN ET AL., THE ANATOMY OF CORPORATE LAW: A COMPARATIVE AND FunCTIONAL APPROACH (2d ed.) (2009); Frank H. Easterbrook \& Daniel R. Fischel, The Corporate Contract, 89 CoLUM. L. REV. 1416 (1989).

3. See generally F.H. Easterbrook \& D.R. Fischel, Limited Liability and the Corporation, 52 U. CHI. L. ReV. 89 (1989); P. Halpern, M. Trebilcock \& S. Turnbull, An Economic Analysis of Limited Liability in Corporation Law, 30 U. TORONTO L.J. 117 (1980).

4. See generally Henry H. Hansmann \& Reinier Kraakman, The Essential Role of Organizational Law, 110 YALE L.J. 387 (2000).

5. See generally BainBridge, The New Corporate Governance, supra note 2; Stephen M. Bainbridge, Director Primacy: The Means and Ends of Corporate Governance, 97 Nw. U. L. REV. 547 (2003) [hereinafter Bainbridge, Director Primacy].

6. See, e.g., Stephen M. Bainbridge, Director Primacy and Shareholder Disempowerment, 119 HaRV. L. ReV. 1735 (2006); Lucian A. Bebchuk, The Case for Shareholder Access to the Ballot, 59 Bus. LAW. 43 (2003); Lucian A. Bebchuk, The Case for Increasing Shareholder Power, 118 HARV. L. REV. 833 (2005) [hereinafter Bebchuk, Shareholder Power]; William W. Bratton \& Michael L. Wachter, The Case Against Shareholder Empowerment, 158 U. PA. L. REV. 653 (2010); Jill E. Fisch, The Destructive Ambiguity of Federal Proxy Access, 61 EMORY L.J. 435 (2012); M. Kahan \& E. Rock, The Insignificance of Proxy Access, 97 VA. L. REV. 1347 (2011); Bernard S. Sharfman, Why Proxy Access is Harmful to Corporate Governance, 37 J. CORP. L. 387 (2012); L.A. Stout, The Mythical Benefits of Shareholder Control, 93 VA. L. REV. 789 (2007).

7. On the "means" versus "ends" dichotomy in corporate governance scholarship, see Bainbridge, Director Primacy, supra note 5. 
For the most part, despite their differences of opinion on other issues, corporate law and governance scholars have tended to agree upon one thing at least: the overarching normative objective of corporate governance - and by implication, corporate law-should be the maximization (or, at least, long-term enhancement) of shareholder wealth. ${ }^{8}$ Indeed this proposition - variously referred to as the "shareholder wealth maximization," "shareholder value," $"$ " or (as will be used here ${ }^{11}$ ) "shareholder primacy" 12 norm-is so ingrained within mainstream corporate governance thinking that it has rarely been subjected to serious policy or even academic question, except for relatively moderate concerns about the appropriateness of the time horizon over which shareholders' collective financial welfare is most appropriately adjudged by managers and boards. ${ }^{13}$

Although in the 1990s corporate governance scholars witnessed the fairly widespread development of competing pluralist or "stakeholder"

8. See, e.g., Henry H. Hansmann \& Reinier Kraakman, The End of History for Corporate Law, 89 GEO. L.J. 439, 439 (2001) [hereinafter Hansmann \& Kraakman, End of History]; Stephen M. Bainbridge, In Defense of the Shareholder Wealth Maximization Norm: A Reply to Professor Green, 50 WASH. \& LEE L. REV. 1423, 1423 (1993) [hereinafter Bainbridge, SWM Norm]; M.C. Jensen, Value Maximisation, Stakeholder Theory, and the Corporate Objective Function, in 7 EUROPEAN FIN. MGMT. 297 (2001) [hereinafter Jensen, Value Maximisation]; EASTERBROOK \& FisCHEL, CORPORATE LAW, supra note 2, at 35-39; Bebchuk, Shareholder Power, supra note 6, at 842-43; Bainbridge, Director Primacy, supra note 5, at 574-92.

9. See, e.g., Robert P. Bartlett, III, Shareholder Wealth Maximization as Means to an End, 38 Seattle U. L. Rev. 255 (2015); Mark J. Roe, The Shareholder Wealth Maximization Norm and Industrial Organization, 149 U. PA. L. REV. 2063 (2001); Bernard S. Sharfman, Shareholder Wealth Maximization and its Implementation Under Corporate Law, 66 FLA. L. REV. 389 (2014); Bainbridge, SWM Norm, supra note 8.

10. See, e.g., William W. Bratton, Enron and the Dark Side of Shareholder Value, 76 TUL. L. REV. 1275 (2002) [hereinafter Bratton, Enron]; Jeffrey N. Gordon, The Rise of Independent Directors in the United States, 1950-2005: Of Shareholder Value and Stock Market Prices, 59 STAN. L. ReV. 1465 (2007); William Lazonick \& Mary O’Sullivan, Maximizing Shareholder Value: A New Ideology for Corporate Governance, 29 ECON. \& SoC'Y. 13 (2000); Jensen, Value Maximisation, supra note 8.

11. For the purposes of this article, the term "shareholder primacy" is preferred because of the present author's view that it best encapsulates the essential functional outcome of the key legal principles in this regard and, in particular, their effect in ensuring the systematic prioritization by corporate management of the collective interests of shareholders over those of other stakeholders (and especially employees) in the event of conflict. See infra Part III.C.

12. See, e.g., John Armour et al., Shareholder Primacy and the Trajectory of UK Corporate Governance, 41 BRIT. J. INDUS. REL. 531 (2003); William W. Bratton \& Michael L. Wachter, Shareholder Primacy's Corporatist Origins: Adolf Berle and The Modern Corporation, 34 J. CORP. L. 99 (2008); Lynn A. Stout, Bad and Not-So-Bad Arguments for Shareholder Primacy, 75 S. CAL. L. REV. 1189 (2002); David Millon, Shareholder Primacy in the Classroom After the Financial Crisis, 8 J. BUS. \& TECH. L. 191 (2013).

13. See, e.g., Michael C. Jensen, Agency Costs of Overvalued Equity, 34 Fin. MGMT. 5 (2005); The Aspen Institute, Overcoming Short-termism: A Call for a More Responsible Approach to Investment and Business Management (September 2009); Lynne L. Dallas, Short-Termism, the Financial Crisis, and Corporate Governance, 37 J. CORP. L. 264 (2012); Marc T. Moore \& Edward Walker-Arnott, A Fresh Look at Stock Market Short-Termism, 41 J. LAW \& Soc. 416 (2014). 
understandings of the corporation's rightful social objectives, ${ }^{14}$ such counter-theories rarely garnered much serious consideration within the mainstream. And, where they have been picked up on beyond their own periphery, it has more often than not been for the purpose of discrediting the general stakeholder governance model due to its alleged practical unworkability. ${ }^{15}$ Consequently, at the turn of the present century-and notwithstanding the United States witnessing what was (at the time) arguably the country's most serious corporate governance failure in the form of the Enron collapse - the shareholder primacy paradigm was for all intents and purposes still alive and well. ${ }^{16}$ Moreover, federal regulatory reforms implemented in the aftermath of the 2007-2008 financial crisis - including mandatory shareholder "say on pay" voting ${ }^{17}$ and opt-in proxy access ${ }^{18}$ - were indicative of a policy agenda, which (somewhat counterintuitively in many peoples' eyes) saw intensification of directors' focus on shareholder welfare as the most appropriate response to the corporate governance and risk oversight lapses exposed in the then recently failed banks. ${ }^{19}$

At long last, though, the zeitgeist would appear to be slowly but surely changing. The financial crisis may not quite have proved the

14. See, e.g., Margaret M. Blair, Ownership and Control, Rethinking Corporate GOVERNANCE FOR THE TwENTY-FIRST CENTURY (1995); John Kay, The Stakeholder Corporation, in STAKeHOLDER CAPITALiSM 125 (Gavin Kelly et al. eds., 1997); Gavin Kelly \& John Parkinson, The Conceptual Foundations of the Company: A Pluralist Approach, in THE POLITICAL ECONOMY OF THE Company 113 (John Parkinson et al. eds., 2000); Luigi Zingales, In Search of New Foundations, 55 J. FIN. 1623 (2000).

15. See Bainbridge, The New Corporate Governance, supra note 2, at 66-67; EASTERBROOK \& FISCHEL, CORPORATE LAW, supra note 2, at 38; Jensen, Value Maximisation, supra note 8 , at 301 .

16. Antoine Reberioux, Does Shareholder Primacy Lead to a Decline in Managerial Accountability, 31 CAMB. J. ECON. 507, 507 (2007). In a legal-academic context, this is exemplified most pertinently by Hansmann and Kraakman's provocative End of History piece, supra note 8, which was published in 2001-albeit shortly before the materialization of the abovementioned Enron debacle. For arguments suggesting that the prevailing shareholder primacy (or "value") norm in U.S. corporate governance was the central factor underlying Enron's collapse, see MICHEL AGLIETTA \& ANTOINe Reberioux, Corporate Governance Adrift: A CritiQue of SHAREHOlder VAlue (2005), ch. 8; Simon Deakin and Suzanne J. Konzelmann, Learning from Enron, in 12 CORPORATE GOVERNANCE: AN INTERNATIONAL REVIEW 134 (2004); Bratton, Enron, supra note 10.

17. See The Dodd-Frank Wall Street Reform and Consumer Protection Act of 2010, Pub. L. No. 111-203, 124 Stat. 1376, § 951.

18. See The Dodd-Frank Wall Street Reform and Consumer Protection Act of 2010, § 971; Marc T. Moore, Corporate Governance in the Shadow of the State 131-32 (2013) [hereinafter MOORE, CORPORATE GOVERNANCE].

19. For a powerful argument to this effect, see Bratton \& Wachter, The Case Against Shareholder Empowerment, supra note 6. Similarly, Bruner claims that the shareholder empowerment movement "appears highly suspect in light of the growing postcrisis empirical literature, which tends to suggest that strong emphasis on the interests of risk-preferring shareholders results in more risk-taking, not less." See Christopher M. BRUNER, CORPORATE GOVERNANCE IN THE COMMON-LAW WORLD: THE POLITICAL Foundations OF SHAREHOLDER POWER 271 (2013). 
watershed moment it was initially heralded as in terms of resetting dominant currents of economic or political opinion. Nonetheless, in the narrower but still important domain of corporate governance thinking and policymaking, the past decade's events have triggered the onset of what promises to be a potentially major paradigm shift in the direction of an evolving PSV consensus. ${ }^{20}$

In essence, the PSV thought consensus is an emerging body of corporate governance scholarship that regards the orthodox U.S. corporate objective of shareholder wealth (or value) maximization as being inherently averse to the purportedly "true" purpose of the corporation as a legal-institutional structure: that is, to protect the long-term productive autonomy of a business organization and its capital base from the destabilizing influence of short-term financial interests. ${ }^{21}$ The central prescriptive tenets of this position are manifested on a practical policy level by the proliferation of benefit corporations (and, relatedly, Certified B Corporations), dual-class voting structures, anti-takeover mechanisms, and other such legal mechanisms designed to afford enhanced insulation to corporate boards and managers against unwanted external pressure from activist shareholders and prospective control acquirers. ${ }^{22}$

On an academic level, this movement is represented by a growing body of influential legal and economic scholarship - including, inter alia, the work by Professor Colin Mayer, to which the Berle VIII Symposium is partly dedicated ${ }^{23}$ - which contests most of the staple ideological tenets of orthodox corporate governance theory. In particular, proponents of the PSV paradigm typically dismiss the common neoclassical equation of shareholder wealth maximization with economic efficiency in the broader social sense. ${ }^{24}$ They also typically eschew individualistic understandings of the corporation (or "firm") in terms of its purported internal bargaining dynamics in favor of alternative conceptual models, which celebrate the

20. Although (at least to the author's best knowledge) the term "post-shareholder-value" has not been utilized within any U.S. or other English-language publication to date, it has previously been used by Josef F.H. Baumüller in the title of his (German-language) management theory book PosT SHAREHOLDER VALUE: ZUKÜNFTIGE UNTERNEHMENSFÜHRUNGSKONZEPTE NACH DEM SHAREHOLDER VALUE-KONZEPT (2010), the latter part of which translates as "Future Management Concepts After the Shareholder Value Concept."

21. See infra Part I.

22. See infra Part II.

23. See generally COLIn MAYER, Firm COMMITMENT: Why the CORPORATION IS FAILING US AND HOW TO RESTORE TRUST IN IT (2013) [hereinafter MAYER, FIRM COMMITMENT].

24. For a critical discussion of the commonly assumed correlation between shareholder wealth maximization and economic efficiency generally, see Paddy Ireland, Defending the Rentier: Corporate Theory and the Reprivatisation of the Public Company, in The Political ECONOMY of THE COMPANY 161-63 (John Parkinson et al. eds., 2000). 
distinctive value of the corporation's inherently autonomous corporeal features. ${ }^{25}$

Of central importance to the PSV thought paradigm is the notion of the corporate legal form as a structural mechanism for indefinitely "locking in" capital so as to facilitate significant future advancements in human progress and well-being. Therefore, the fundamental problem is not the public corporation itself but rather the way in which this invaluable vehicle of economic and social development has allegedly been manipulated in the service of objectives that are averse to its fundamental nature. From this perspective, shareholder primacy is presented as an undesirable and, moreover, unnecessary social evil, which has the effect of undermining (if not negating outright) the corporation's core structural attributes for the benefit of short-term financial interests and at the corresponding expense of current and future humanity at large. ${ }^{26}$

It is submitted that evidence of a potential drift from the formerly dominant shareholder primacy paradigm in corporate governance is additionally apparent on a practical policymaking level today, not least in the rapid proliferation of benefit corporations as a viable and popular alternative legal form to the orthodox commercial corporation. ${ }^{27}$ At the same time, the apparently increasing use by U.S.-listed firms of dual-class voting structures designed to insulate management from "outside" capital market pressures, coupled with the seemingly greater flexibility afforded to boards over recent years in defending against unwanted takeover bids from so-called corporate "raiders" both provide additional cause to question the longevity of the shareholder-oriented corporate governance status quo. ${ }^{28}$

Against the above background, this Article critically evaluates the developing PSV paradigm in corporate governance scholarship and practice with particular reference to Mayer's influential theory of the corporation as a unique, long-term "commitment device." ${ }^{29}$ Part I of this

25. On these core aspects of the general PSV corporate governance thought paradigm, see infra Part I.

26. On these issues, likewise see infra Part I.

27. A Benefit Corporation differs from an orthodox for-profit corporation principally because it is expressly subject to the alternative corporate purpose of creating general public benefit even in situations where effective managerial pursuit of this goal may come at the cost of reduced risk-adjusted economic returns for shareholders. However, in contrast to a standard non-profit organization, a Benefit Corporation is generally not subject to any specific charitable purpose and does not enjoy taxexempt status. It also typically retains certain commercial-corporate structural features including the capacity to distribute profits to shareholders. This is subject to the practical proviso that a Benefit Corporation's management is likely to enjoy greater freedom to resist external capital market pressures to distribute earnings than would ordinarily be the case with a for-profit corporation. For a more detailed discussion of a Benefit Corporation's distinctive legal features, see infra Part II.A.

28. On these issues, see infra Part II.

29. MAYER, FIRM COMMITMENT, supra note 23, at 112. 
Article analyzes the key features of the PSV thought paradigm including (but not limited to) Mayer's "firm commitment" thesis. Part II examines how the general PSV paradigm has manifested on a policy level today within corporate governance practice, looking in particular at the increasing demand for the B Corp ${ }^{30}$ and benefit corporation forms in the United States over recent years and also the corresponding popularity of managerial hostile takeover defenses and dual-class voting structures. While evolving PSV institutional mechanisms such as benefit corporations and dual-class share schemes are prima facie encouraging from a social perspective, there is cause for skepticism about their capacity to become anything more than a relatively niche or peripheral feature of the U.S. public corporations landscape. This is principally because such measures, despite their apparent reformist potential, are still ultimately quasicontractual, and thus essentially voluntary in nature, meaning that they are unlikely to be adopted in a public corporations context except in extraordinary instances.

Accordingly, Part III examines whether there is a plausible normative justification for placing such measures on a firmer regulatory footing as a means of more assertively implementing the PSV corporate governance agenda in practice. It posits that such measures-irrespective of the extent of their adoption over the coming years-ultimately should remain quasi-contractual and voluntary in nature, as opposed to being placed on any sort of mandatory basis. That is, at least pending fundamental reform of the broader social-institutional context to the orthodox shareholder-oriented corporation, and-in particular-the United States' predominantly private (i.e., non-statist) pensions framework.

\section{FIRM COMMITMENT AND THE POST-SHAREHOLDER-VALUE THOUGHT PARADIGM}

\section{A. Mayer's Firm Commitment Thesis}

At the heart of the PSV intellectual movement sits the book which was partly the subject of the Berle VIII Symposium, namely Colin Mayer's ${ }^{31}$ excellent work Firm Commitment: Why the Corporation Is

30. As will be explained further below, the essential difference between (i) a Benefit Corporation and (ii) a B Corp is that whereas the former type of organization is formally established under applicable (State) legislation, and thus requires specific public registration the latter is simply a market-provided accreditation available to existing commercial corporations meeting certain privately-formulated eligibility criteria, which in itself does not entail outright entity reconstitution. For a more detailed explanation of the distinction between these dual phenomena, see infra Part I.A.

31. Colin Mayer is the Peter Moores Professor of Management Studies at Saïd Business School at the University of Oxford. He is one of the world's foremost thinkers on corporate governance and 
Failing Us and How to Restore Trust in It. ${ }^{32}$ Mayer's 2013 monograph represents a central and highly influential component of the developing PSV thought consensus. In particular, it advances and develops an idea that is pivotal to contemporary PSV ideology, which is the notion of the corporation as a sophisticated, long-term "commitment device." 33

Essentially, this idea denotes the unique structural capacity of an incorporated business entity to act as an effective, long-term store for equity investors' capital by ensuring that such funds - once committed to the corporate enterprise-become permanent and thus unsusceptible to future withdrawal by investors (or, by the same logic, their personal creditors) on unilateral demand. ${ }^{34}$ Mayer claims that, theoretically, this effective asset lock that the corporate legal form creates enables investors to voluntarily restrain themselves ex ante from exercising control over the firm's capital reservoir in ways that are prone to harm the interests of other, more vulnerable firm participants or interests. ${ }^{35}$ This especially applies with respect to future situations where such harmful action might actually prove to be in investors' best interests at the relevant time, at least in the short run. ${ }^{36}$

From a corporate governance point of view, the implication is that management can consequently make credible long-term undertakings to protect the continuing value of important nonfinancial investments advanced by other firm participants, especially the human capital committed to the corporation by its key employees. These undertakings are, in turn, likely to engender reciprocal trust and loyalty within the firm's various stakeholder relations. Mayer places considerable emphasis on the notion of "self-restraint" in general as a necessary precondition to long-term human well-being ${ }^{37}$ and particularly as an essential means of eliciting trust on the part of those who benefit from such restraint. ${ }^{38}$ According to this view, while self-restraint is averse to the pursuit of immediate gratification, it is nonetheless justifiable in accordance with one's own (enlightened) self-interest. In particular, self-restraint is

\footnotetext{
finance, particularly with respect to the relationship between corporations and financial markets. His book FIRM COMMITMENT (supra note 23) represents a key, although by no means exclusive, example of his pioneering scholarship in this area. See also Colin Mayer, New Issues in Corporate Finance, 32 EUR. ECON. REV. 1167 (1988); Julian Franks \& Colin Mayer, Hostile Takeovers and the Correction of Managerial Failure, 40 J. Fin. ECON. 163 (1996); Julian Franks \& Colin Mayer, Ownership and Control of German Corporations, 14 REV. FIN. STUD. 943 (2001).

32. MAYER, FIRM COMMITMENT, supra note 23.

33. Id. at 112 .

34. Id. at $145-46$.

35. Id. at 5 .

36. Id. at 124 .

37. Id. at 20.

38. Id. at 145.
} 
purportedly motivated by the potential long-term benefits that are likely to come from not encroaching on other parties' interests.

It follows from the above perspective that the separation of ownership and control within Anglo-American public corporations-far from being a problem that merits a corresponding "solution" (as orthodox scholarship typically avers) ${ }^{39}$-is contrarily a source of opportunity in itself, insofar as it facilitates managerial responsiveness to important third party interests, which are typically not protected contractually. ${ }^{40}$ Mayer posits that "[i]n an exact reversal of the problem suggested by Berle and Means of dispersed shareholders, from the perspective of firm commitment, the separation of ownership and control is a benefit, not a cost." 41 This is because "[b]y separating ownership and control of the corporation, shareholders are able to delegate authority to directors who can make commitments to other parties that shareholders would like but are unable credibly to provide themselves." 42

To this end, Mayer supports the notion of: (i) control and (ii) liquidity as being mutually substitutable attributes, whereby investors acquire the capacity readily to convert their shareholdings into cash at any time on the (external) secondary capital market in exchange for surrendering influence over aspects of (internal) business policy. ${ }^{43}$ Thus, Mayer would appear to regard a more or less complete bifurcation of liquidity and control as a positive governance feature, at least for some public corporations. ${ }^{44}$ Mayer claims that this bifurcation enables management to make credible longterm commitments to nonshareholder groups, which would be otherwise impossible if shareholders were in a position to pressurize for the unilateral revocation of those undertakings in the future. ${ }^{45}$

However, according to Mayer, the credibility of investors' capital commitments is seriously undermined by capital market institutions that enable shareholders collectively to lobby for withdrawal of their invested funds from the firm on demand. This in turn undermines the ensuing degree of stakeholder trust likely to be placed in the firm and its management, thereby eroding the commitment-facilitating value of the corporate form in practice. ${ }^{46}$ Specifically, Mayer claims that hostile

39. For a critical analysis of this general feature of orthodox corporate governance scholarship, see Marc T. Moore \& Antoine Rebérioux, Revitalizing the Institutional Roots of Anglo-American Corporate Governance, 40 ECON. \& SOC'Y 84 (2011).

40. MAYER, FIRM COMMITMENT, supra note 23, at 6.

41. Id. at 147.

42. Id. at 153 .

43. See id. at $145-50$.

44. Id. at 147.

45. See id. at 210-12.

46. Id. at 139. 
takeovers motivated by the apparent objective of "unlocking shareholder value" enables prospective control-acquirers to offer a bid premium directly to shareholders irrespective of management support. ${ }^{47}$ Such transactions consequently provide a unique opportunity for a prospective corporate acquirer (or "raider") to wrest control over the firm's internal capital reserves from its incumbent management, which facilitates the effective withdrawal of these reserves at any given time in the future. ${ }^{48}$ The overall effect is to make it impossible for investors to make any sort of credible precommitment of their capital to the firm on a permanent or even long-term basis, given the potential opportunity that they may have collectively participated in the effective withdrawal of these funds in future. ${ }^{49}$ This serves to undermine significantly the firm's role as a longterm commitment device in the above sense. ${ }^{50}$

Furthermore, Mayer argues that in the presence of an active market for corporate control, managers of public corporations are consequently pressurized to distribute high levels of capital to shareholders rather than retain these reserves for purposes of internal enterprise stability and expansion. ${ }^{51}$ In this way, managers in effect preclude potential future attempts to "unlock" these reserves either via an outright control bid, or else by means of activist investor interventions geared to acquiring significant minority shareholder influence. ${ }^{52}$ Moreover, in Mayer's view, hedge funds and other especially activist shareholders, by pressurizing management to return greater amounts of cash to shareholders in the form of dividends or (as is more customary) stock buybacks, undermine the corporation's capacity to make credible commitments to other stakeholders. ${ }^{53}$ This is because depletion of the firm's internal capital reserves creates a greater likelihood of future business financing shortfalls necessitating resort to external capital markets, thereby rendering management subservient to shareholders' (in priority to other stakeholders') collective demands on an ongoing basis. ${ }^{54}$ Accordingly, Mayer supports the ready availability of legal institutional mechanisms that are designed to offset or even negate such capital market pressures in appropriate instances. ${ }^{55}$

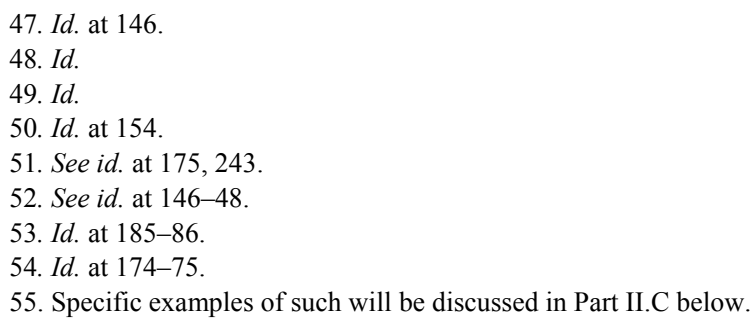


As a conceptual critique of prevailing Anglo-American corporate governance norms, Mayer's thesis is both distinctive and compelling. Arguably, the most remarkable feature of Mayer's argument is his view that, in terms of tackling the dilemma of how to engender enhanced firm commitment, the corporate form is the solution rather than the underlying problem itself. ${ }^{56}$ In other words, the proper remedial approach is not that of reforming the basic structure of the public corporation itself (which remains fundamentally sound and sensible), but rather in seeking to ensure that its core structural qualities are better protected against outside encroachment from destructive capital market influences. ${ }^{57}$ From a normative standpoint, this is a highly convincing claim with which the present author has much sympathy. However, whether Mayer's key prescriptive assertions are capable of being effectively implemented in practice, at least without themselves occasioning adverse collateral social impacts, is a more contestable point that will be analyzed later in this Article. $^{58}$

\section{B. The Broader Post-Shareholder-Value Thought Paradigm}

The central focus of Mayer's work on the theoretical (if not actual) autonomy of the corporate form from extraneous investor interference resonates with a similar current of opinion developing within contemporary legal scholarship, which likewise seeks to highlight the value of the corporation's inherent structural neutrality vis-à-vis extraneous capital market interests. The intellectual precursor to this evolving thought consensus was Margaret Blair and Lynn Stout's now-classic 1999 exposition of the corporation as a so-called "team production" device. ${ }^{59}$ Blair and Stout's influential theory of the firm

56. In this regard, Mayer asserts that: "[c]orporations are commitment devices ... [and] achieve this by making the capital that their owners invest in them permanent." MAYER, FIRM COMMITMENT, supra note 23, at 145 .

57. Indeed, Mayer qualifies his general exaltation of the corporate form's commitmentfacilitating capacity with the significant proviso that: "[a]t least that in principle is how [corporations] create commitment ... [but that t]he permanent capital of the firm is no longer permanent [insofar as] it can be extracted in acquisitions that are paid for by cash." Id. at 146.

58. See infra Parts II and III.

59. Margaret Blair is the Milton R. Underwood Chair in Free Enterprise at Vanderbilt Law School and a foremost economic thinker within the overlapping fields of corporate law, governance, and finance. Her 1995 book OWNERSHIP AND CONTROL: RETHINKING CORPORATE GOVERNANCE FOR THE TWENTY-FIRST CENTURY (1995) is one of the most path-breaking and influential corporate governance monographs of recent times, particularly in its sophisticated economic rationalization of the role of key nonshareholder constituencies within corporate governance. BLAIR, supra note 14 . Lynn Stout is a Distinguished Professor of Corporate \& Business Law at Cornell Law School and one of the world's most influential and renowned authorities on, inter alia, corporate law, corporate governance, and securities regulation. Her 2012 book THE SHAREHOLder VAlue Myth: How Putting Shareholders First Harms InVestors, Corporations, and the Public (2012) 
depicts equity investors as voluntarily surrendering any formal legal entitlement and demanding that directors dutifully serve their private interests. ${ }^{60}$ This purportedly frees up corporate boards to balance and mediate between the conflicting claims of different stakeholders, with a view to protecting valuable enterprise-specific investments undertaken by employees and other key corporate constituents in addition to the value of shareholders' equity capital. ${ }^{61}$ Thus, the ultimate aim of corporate governance (and, correspondingly, corporate law), according to Blair and Stout, is to encourage the continuing advancement of such specialized financial and nonfinancial investments in the future, thereby enhancing the long-term economic output of the corporation's productive "team" as a whole. $^{62}$

Both Margaret Blair and Lynn Stout went on to develop the fundamental rationality of the team production model in their more recent individual work. In particular, Blair has further elaborated on the notion of the corporate legal form as a long-term capital "lock-in" device. ${ }^{63}$ Meanwhile, Stout has advanced a novel understanding of the corporation in terms of an intergenerational wealth transfer mechanism (or metaphorical "time machine") that enables both: (i) the locking-in of capital resources from the primary market for the benefit of long-term production projects, which promise gains only in the distant future; and - correspondingly - (ii) the immediate realization by present investors of anticipated future corporate profit streams from such long-term

[hereinafter Stout, Shareholder VAlue MYth] is one the most influential and high-profile corporate law monographs of recent times, particularly in its questioning of the common (and arguably erroneous) belief that U.S. corporate boards are legally bound to maximize shareholder value as a direct consequence of their legal fiduciary duties. Blair and Stout's "team production" thesis, for which they are (at least jointly) best known, is expounded in their now classic 1999 article, A Team Production Theory of Corporate Law, 85 VA. L. REV. 247 (1999). As well as being one of the most downloaded papers on the SSRN research database, this article has also been the subject matter of a previous Berle Symposium (in 2014). Its profound influence within the corporate law academy today is thus beyond question.

60. In their landmark 1999 article, Blair and Stout posit that: "[t]he act of forming a corporation ... means that no one team member is a 'principal' who enjoys a right of control over the team. ... [ [but rather] once they have formed a corporation and selected a board, the team members have created a new and separate entity that takes on a life of its own and could, potentially, act against their interests, leading them to lose what they have invested in the enterprise." Id. at 277.

61. See id. at $278-81$.

62. In this regard, Blair and Stout assert that, "the directors are trustees for the corporation itself-mediating hierarchs whose job is to balance team members' competing interests in a fashion that keeps everyone happy enough that the productive coalition stays together." Id. at 280-81.

63. See generally Margaret M. Blair, Locking in Capital: What Corporate Law Achieved for Business Organizers in the Nineteenth Century, 51 UCLA L. REV. 387 (2003). 
initiatives via monetization of their risk-adjusted value on the secondary capital market. ${ }^{64}$

Meanwhile, in a separate but related line of work, Stout has challenged the common assumption that the shareholder primacy norm is an established proposition of corporate law. ${ }^{65}$ Stout posits that " $[\mathrm{t}]$ here is no solid legal support for the claim that directors and executives in US public corporations have an enforceable legal duty to maximize shareholder wealth," 66 but-contrarily-that, "American corporate law ... fiercely protects directors' power to sacrifice shareholder value in the pursuit of other corporate goals. ${ }^{.67}$ In this way, Stout sought to build not just normative but also positive-doctrinal support for the notion of depersonalized corporate neutrality that lies at the heart of her sophisticated PSV conception of the corporation. ${ }^{68}$

Working along similar theoretical lines to the above authors, Andrew Schwartz ${ }^{69}$ recently rationalized the corporate entity's unique perpetual existence as a means of enabling it to invest "immortally" in productive operations spanning a potentially infinite future time period. ${ }^{70}$ Likewise, Andrew Keay's ${ }^{71}$ elegant Entity Maximization and Sustainability (or "EMS") Model of the corporation emphasizes the long-term survival and value enhancement of the corporate entity itself, rather than the welfare of its shareholders, as the purportedly central corporate objective. ${ }^{72}$

64. See generally Lynn A. Stout, The Corporation as Time Machine: Intergenerational Equity, Intergenerational Efficiency, and the Corporate Form, 38 SEATTLE U. L. REV. 685 (2015).

65. See generally Stout, Shareholder VAlue MYth, supra note 59; Lynn A. Stout, Why We Should Stop Teaching Dodge v. Ford, 3 VA. L. \& BUS. REV. 163 (2008) [hereinafter Stout, Dodge v. Ford].

66. Stout, SHAREHOLDER VALUE Myth, supra note 59, at 25.

67. Id. at 32 .

68. See id. ch. 2; Stout, Dodge v. Ford, supra note 65, at 168-72.

69. Andrew Schwartz is an Associate Professor of Law at Colorado Law School and one of the most exciting and innovative emerging thinkers in the fields of corporate and securities law, particularly with respect to the implications of the corporation's unique legal form.

70. See generally Andrew A. Schwartz, The Perpetual Corporation, 80 Geo. WASH. L. ReV. 764 (2012); Andrew A. Schwartz, Corporate Legacy, 5 HARV. Bus. L. REV. 237 (2015).

71. Andrew Keay is a Professor of Corporate and Commercial Law at the University of Leeds in the United Kingdom. He is one of the most prolific and influential corporate law scholars in the common law world, particularly in the fields of directors' duties and corporate governance theory.

72. See generally Andrew Keay, Ascertaining the Corporate Objective: An Entity Maximisation and Sustainability Model, 71663 ModERN L. REV. (2008). In a fundamentally similar vein, Daniel Attenborough has developed a sophisticated normative characterization of the corporation in terms of his purported Equitable Maximization and Viability (EMV) Principle, which essentially posits that the legitimate dual objective of corporate controllers should be to "(i) respect, protect, and fulfil the demonstrable, legitimate interests and expectations of the constituent groups that contribute to the corporation; and (ii) to facilitate the corporation's viability so that its future is guaranteed with sufficiently high probability." See Daniel Attenborough, Giving Purpose to the Corporate Purpose Debate: An Equitable Maximisation and Viability Principle, 32 Legal STUD. 4, 4 (2012). 
Simon Deakin, ${ }^{73}$ further expanding on these core and interlocking themes of organizational neutrality and perpetuity, has conceptualized the corporation in terms of a "commons": that is, "a shared resource whose sustainability depends on the participation of multiple constituencies in its governance (not just shareholders, but employees, core suppliers and customers)." ${ }^{\prime 74}$ With regard to the corporation's key distinguishing structural qualities, Deakin emphasizes the "permanence" 75 of the autonomous legal entity, the long-term "continuity" 76 of its asset base, and-relatedly - the "insulation" 77 of its board from direct shareholder pressure. Deakin claims that, "[v]iewing one user group as having priority over the others in the use it can make of common resources and in its power to hold the managers of the resource to account is not compatible with the maintenance of the resource over time." "78 Accordingly, and in terms somewhat reminiscent of the abovementioned team production model, Deakin asserts that the corporation should be understood as "subject to a number of multiple, overlapping and potentially conflicting property type claims on the part of the different constituencies or stakeholders that provide value to the firm.",79

Arguably, all of the above works varyingly form part of an evolving PSV thought consensus. ${ }^{80}$ Despite the specific nuances of each component theory, some core unifying themes arguably emanate from much of this body of scholarship. Most significant is the common normative assertion that the corporation, far from being rightfully subject to shareholders' determinative control or influence, is contrarily a neutral organization whose autonomous existence and interests entirely transcend those of its particular body of shareholders at any given point in time ${ }^{81}$ From this it

73. Simon Deakin is a Professor of Law at the University of Cambridge and Director of the Cambridge Centre for Business Research. He is one of the world's most eminent and respected legal and social-scientific scholars, whose work spans multiple subject areas and disciplines but most pertinently corporate governance, labour law, law and economics, and law and development.

74. See Simon Deakin, The Corporation as Commons: Rethinking Property Rights, Governance and Sustainability in the Business Enterprise, 37 QUEEN's L.J. 339, 339 (2012). The basic conceptual notion of a "commons" in the sense referred to by Deakin was first authoritatively developed by Garrett Hardin in his classical piece, The Tragedy of the Commons, 162 SCIENCE 1243 (1968).

75. Deakin, supra note 74, at 353.

76. Id.

77. Id. at 360 .

78. Id. at $377-78$.

79. Id. at 381 .

80. Indeed, the potential emergence of a new thought consensus in this regard has been noted by Stout, who remarks (albeit somewhat sanguinely, perhaps) that, "among experts, shareholder value dogma shows signs of being in decline," such that, "the shareholder primacy paradigm is failing, and alternative paradigms are rising to take its place." See StOUt, SHAREHOLDER VAlue MYth, supra note 59 , at 114 .

81. In this regard, the fundamental normative slant of the PSV position is conspicuously reminiscent of the reformist element of Berle and Means' classical 1932 thesis, 
follows the additional common proposition that corporate law not only should - but generally does - afford overriding constitutional protection to the autonomy, integrity, and perpetuity of the corporate legal entity vis-à-vis the private interests and demands of any of its specific constituents, and not least those of, its current shareholders.

\section{The Post-Shareholder-VALUe Policy PARADIGM}

Somewhat curiously, and consistent with the underpinning contractarian rationality of the orthodox shareholder primacy position, proponents of the PSV paradigm would appear to exhibit a general preference — both academically and on a policy level—-for flexible private ordering as the principal means of implementing appropriate corporate governance innovations in practice. In this respect, Mayer's Firm Commitment $^{82}$ thesis stands out as a notable case in point. Indeed, consistent with his understanding of enhanced firm stakeholder commitment as something motivated by investors' own enlightened self-restraint, Mayer eschews coercive or universalistic regulatory measures in favor of more nuanced and firm-specific private ordering practices. ${ }^{83} \mathrm{He}$ emphasizes that because "there is not a universally superior form of ownership and governance of firms which is suited to all firms at all times," 84 it follows that, "[t]he balancing of commitments and control is a delicate activity that will be highly specific to the particular nature and context of the corporation." 85

Mayer believes that, against this background, "[t]he search for uniform rules of governance is both pointless and damaging," ${ }^{86}$ while "[r]egulations that impede firms' choice of their appropriate arrangements undermine their competitiveness. ${ }^{, 87}$ Interestingly, Mayer attributes the comparative success of the U.S. corporate financing and governance system to the "exceptional degree of diversity" 88 that it permits,

and - in particular - these authors' oft-cited (albeit somewhat tentative) prediction that the function of managing the modern public corporation might evolve into that of "a purely neutral technocracy," balancing the respective claims of its various stakeholders without necessarily affording overriding primacy to any particular constituency's interests. See ADOLF A. BERLE AND GARDINER C. MEANS, THE MOdern CORPORATION AND PRIVATE PROPERTY 312-13 (Harcourt, Brace \& World, Inc. rev. ed. 1968) (1932).

82. MAYER, FIRM COMMITMENT, supra note 23.

83. See id. at $187-90$.

84. Id. at 189 .

85. Id. at 188

86. Id.

87. Id. at 189. In this regard, Mayer is critical of the strong influence wielded by international corporate governance codes today, which-he claims - compel excessive uniformity often with unsuitable practices. See id. at 231.

88. Id. at 230 . 
particularly with respect to those public corporations that wish to deviate from the norms of widely dispersed share ownership and shareholder primacy. ${ }^{89}$ Therefore, Mayer advocates that, "policymakers should examine whether there are features of their laws, regulations, or conventions that may discourage variety and experimentation." 90

\section{A. The Benefit Corporation Framework}

As an example of the sort of institutional diversity in corporate governance that Mayer would appear to support, the developing benefit corporation framework is highly pertinent. In essence, the benefit corporation is a novel, alternative legal form to the standard commercial corporation, which is now statutorily available in the majority of the United States. ${ }^{91}$ Despite its present statutory status, the benefit corporation actually derives from purely private origins in its original guise as the Certified B Corporation (or "B Corp"). ${ }^{92}$ The B Corp is a pioneering corporate certification product provided by the Pennsylvania-based nonprofit organization B Lab. ${ }^{93}$ This facility was initially motivated by a perceived demand from prospective incorporators for a form of corporate entity that enables the carrying on of an essentially for-profit business but with a guiding social objective other than the conventionally understood one of shareholder wealth maximization..$^{94}$ Well-known businesses that have opted for B Corp status over recent years include the online craft

89. Mayer notes how this particular aspect of the U.S. environment is in notable contrast to the UK, where the institutional features of a widely dispersed system - including an unimpeded market for corporate control - are much more firmly entrenched via regulation and entrenched capital market norms. See id.

90. Id. at 254. As a pertinent example in this regard, Mayer cites "impediments to issuing more than one class of share with different voting rights deriving from corporate law, financial regulation, or the preferred practices of financial institutions and markets[.]" Id. at 254-55. On the purported benefits of dual-class voting structures from a PSV perspective, see infra Part II.D.

91. The most conspicuous (although by no means only) example of such is the relevant Delaware legislation is set out in Subchapter XV of the Delaware General Corporation Law under the heading "Public Benefit Corporations.” DEL. CoDE ANN. tit. 8, §§ 361-368 (West 2013).

92. See What are B Corps?, B LAB, https://www.bcorporation.net/what-are-b-corps [https://perma.cc/85GK-TTMJ].

93. See About B Lab, B LAB, https://www.bcorporation.net/what-are-b-corps/about-b-lab [https://perma.cc/BTU9-6WZP].

94. See William H. Clark, JR. et al., White Paper, The NeEd and Rationale for the BENEFIT CORPORATION: WHY IT IS THE LEGAL FORM THAT BEST ADDRESSED THE NEEDS OF SOCIAL ENTREPRENEURS, InVEStORs, AND, Ultimately, the Public 5-6 (Jan. 2013), http://benefitcorp.net/sites/default/files/Benefit_Corporation_White_Paper.pdf [https://perma.cc/ 7MFM-FPQH] [hereinafter CLARK ET AL., WHITE PAPER]. 
bazaar, Etsy, ${ }^{95}$ Ben \& Jerry's,${ }^{96}$ and the socially responsible California clothing brand Patagonia. ${ }^{97}$ Moreover, in 2013 the Colorado-based firm, Rally Software, ${ }^{98}$ became the first B Corp to undertake a public offering of its shares ${ }^{99}$ with Etsy following suit two years later by launching the largest B Corp IPO to date. ${ }^{100}$

The B Corp certification was designed for those incorporators who intend their firms to pursue an ultimate social benefit goal, while - unlike in the case of a charitable nonprofit organization - still maintaining the capacity to attract outside finance on commercial terms by promising the future return of some funds to investors. ${ }^{101}$ Following the Certified B Corporation's initially perceived success as a market accreditation service, its essential structure has since been enshrined on a formal legislative footing within thirty-two states (including the District of Columbia) in the guise of the benefit corporation. ${ }^{102}$ This implementing group of states notably includes Delaware, where such entities are formally titled Public Benefit Corporations. ${ }^{103}$

In its (commonly adopted) model form, the benefit corporation framework exhibits three core legal features, which together are expressly designed to offer "entrepreneurs and investors the option to build, and invest in, a business that operates with a corporate purpose broader than maximizing shareholder value and that consciously undertakes a responsibility to maximize the benefits of its operations for all stakeholders, not just shareholders." 104 To this end, the first key distinguishing feature of the benefit corporation (in contrast to a standard

95. About Etsy, ETSY, https://www.etsy.com/uk/about/?ref=ftr [https://perma.cc/PE5F-B5EB].

96. About Us, BEN \& JERRY's, http://www.benjerry.com/about-us/b-corp [https://perma.cc/3L7P-7X44]. Ben \& Jerry's is a wholly-owned subsidiary of the Anglo-Dutch global conglomerate Unilever plc.

97. Patagonia's Mission Statement, PATAGONIA, https://www.patagonia.com/companyinfo.html [https://perma.cc/DGB6-Z26L].

98. In May 2015, Rally Software was acquired by CA Technologies, Inc. See Press Release, CA Technologies, CA Technologies Agrees to Acquire Rally Software, Accelerates Ability for Businesses to Build Transformative Applications Quickly (May 27, 2015), http://www.ca.com/us/ company/newsroom/press-releases/2015/ca-technologies-agrees-to-acquire-rally-software.html.

99. Peri Schweiger \& Jackie Marcus, Etsy and the B Corp IPO: Sustainability Meets Wall Street, TRIPLE PUNDiT (Apr. 27, 2015), http://www.triplepundit.com/2015/04/etsy-and-the-b-corp-iposustainability-meets-wall-street/ [https://perma.cc/6MHA-JYBV].

100. Etsy's widely-reported April 2015 IPO on Nasdaq valued the firm at $\$ 3.38$ billion. See id. 101. CLARK, JR. ET AL., supra note 94, at 6.

102. See generally Why Pass Benefit Corporation Legislation, BENEFIT CORP., http://benefitcorp.net/policymakers/why-pass-benefit-corporation-legislation [https://perma.cc/ XTH8-CPBY]. On the Benefit Corporation phenomenon generally, see generally CLARK ET AL., WHITE PAPER, supra note 94; William H. Clark, Jr. \& Elizabeth K. Babson, How Benefit Corporations Are Redefining the Purpose of Business Corporations, 38 WM. Mitchell L. ReV. 817 (2012).

103. See Del. Code ANN. tit. 8, § 362(a) (West 2016).

104. MODEL BENEFIT CORP. LEGIS. § $101 \mathrm{cmt}$. (2016). 
commercial corporation) is its alternative corporate purpose of "creating general public benefit." " 105 This criterion is expressly defined by the model legislation as requiring "consideration of all of the effects of the business on society and the environment." 106 Meanwhile, the Delaware Public Benefit Corporations legislation adds the further provision that such firms should be intended to produce "a positive effect (or reduction of negative effects) on one or more categories of person, entities, communities or interests (other than stockholders in their capacities as stockholders) including, but not limited to, effects of an artistic, charitable, cultural, economic, educational, environmental, literary, medical, religious, scientific or technological nature." 107

The above global mandate is alongside any further "specific public benefit purposes" 108 that the firm's incorporators elect to add to its articles of incorporation including:

(1) providing low-income or underserved individuals or communities with beneficial products or services; (2) promoting economic opportunity for individuals or communities beyond the creation of jobs in the normal course of business; (3) protecting or restoring the environment; (4) improving human health; (5) promoting the arts, sciences, or advancement of knowledge; (6) increasing the flow of capital to entities with a purpose to benefit society or the environment; and (7) conferring any other particular benefit on society or the environment. ${ }^{109}$

Notably, the Delaware legislation contains the additional specification that such firms should "operate in a responsible and sustainable manner," 110 and thus "shall be managed in a manner that balances the stockholder's pecuniary interests, the best interests of those materially affected by the corporation's conduct, and the public benefit or public benefits identified in its certificate of incorporation."111

This alternative corporate purpose is supplemented by the second and, from a corporate governance standpoint at least, arguably most significant legal feature of the benefit corporation framework. This is a corresponding multistakeholder director's fiduciary duty, which is expressly designed to broaden the legitimate focus of benefit corporation boards beyond directors' conventionally perceived fiduciary responsibility

105. Id. §201(a).

106. Id. § 102 .

107. DEL. CODE ANN. tit. $8, \S 362$ (b).

108. MODEL BENEFIT CORP. LEGIS. § 201(b) (2016).

109. Id. $\S 102$.

110. DEL. CODE ANN. tit. $8, \S 362$ (a).

111. Id. 
to further the specific interests of shareholders. ${ }^{112}$ Accordingly, in determining whether a proposed course of action or inaction is in the best interests of a particular benefit corporation, the Model Benefit Corporation Legislation provides that its directors should have regard to the likely consequences thereof not just for shareholders but also for other relevant stakeholder interests including employees, customers, local communities, society more generally, and the local and global environment. ${ }^{113}$

Moreover, as a general default rule the directors of a benefit corporation are expressly not required to give priority to any particular social interest or factor, but rather are expected to strike an appropriate balance between these various considerations according to directors' own reasonable assessment of their respective materiality to the firm's creation of general (and, where appropriate, specific) public benefit. ${ }^{114}$ In this context, the business judgment rule expressly operates to protect any such exercises of directorial discretion from subsequent shareholder or stakeholder reproach, subject to the usual proviso that the relevant board decision has been carried out on a rational, disinterested, and reasonably informed basis. ${ }^{115}$

One further key legal feature of the benefit corporation, which reinforces the above alternative business purpose and supporting director's duty, is the requirement to compile and publish an annual (or, in Delaware, biannual) benefit report. ${ }^{116}$ This report should contain-inter alia-a narrative account of the firm's pursuit and creation of general public benefit (and, where appropriate, any additionally specified public benefits) in accordance with the above statutory definition of the term(s), together with an assessment of the overall social and environmental performance of the relevant firm as measured against a credible third party standard provided by an appropriate private verification agency (e.g., B Lab). ${ }^{117}$ The Model Benefit Corporation Legislation requires that a publicly traded

112. Indeed, the Model Benefit Corp. Legislation expressly states that, "[t]his [director's multistakeholder duty] section is at the heart of what it means to be a benefit corporation." MODEL BENEFIT CORP. LEGIS. § $301 \mathrm{cmt}$ (2016).

113. MODEL BENEFIT CORP. LEGIS. § 301(a)(1).

114. Id. $\S 301(\mathrm{a})(3)$. In a similar vein, the Delaware legislation provides that, "[t]he board of directors shall manage or direct the business and affairs of the public benefit corporation in a manner that balances the pecuniary interests of the stockholders, the best interests of those materially affected by the corporation's conduct, and the specific public benefit or public benefits identified in its certificate of incorporation.” DEL. CODE ANN. tit. 8, § 365(a).

115. Model BeNEFIT CORP. Legis. § 301(e); Del. CODE ANN. tit. $8, \S 365(\mathrm{~b})$.

116. Model Benefit CoRp. Legis. $\S \S 401-02$; Del. Code ANN. tit. $8, \S 366(\mathrm{~b})$

117. MODEL BENEFIT CORP. LEGIS. § 401(a). Under the corresponding Delaware provision, measurement of corporate social and/or environmental performance against an objective third party standard is not a mandatory or even default requirement, but rather is subject to affirmative opt-in under a particular Public Benefit Corporation's charter or bylaws. See Del. CoDE ANN. tit. 8, $\S 366(\mathrm{c})(3)$. 
benefit corporation's annual benefit report contain an annual compliance statement by the firm's appointed "benefit director" 118 to the effect that, in the relevant officer's opinion, the firm has conformed to its general (and, where appropriate, specific) benefit purpose(s) in all material respects over the reporting period. ${ }^{119}$ The benefit director's annual compliance statement must further confirm that the benefit corporation's directors have complied with their abovementioned stakeholder-interest-balancing duty and should also detail any incidences of deviation by the firm or its directors from their statutory responsibilities in the above respects. ${ }^{120}$

\section{B. Practical Limitations of the Benefit Corporation Framework}

In terms of the fundamental rationality of the PSV paradigm described above, the benefit corporation framework would appear to represent an attractive policy development. Consistent with the logic of Mayer's Firm Commitment ${ }^{121}$ thesis, such entities arguably constitute an important self-restraint mechanism, enabling investors to "tie their own hands" by surrendering ex ante the privileged legal status that they would otherwise enjoy (at least within an orthodox commercial corporate setting) as the principal collective beneficiary of directors' fiduciary accountability. Instead, benefit corporation boards assume a broader based responsibility to pursue the creation of overall public benefit from the firms' operations in the particular manner that they reasonably see fit. While it is envisaged that shareholders will frequently derive longterm benefits from a firm's publicly oriented activities, such benefits will accrue as an indirect or collateral result of management's pursuit of the corporate public benefit purpose, as opposed to being a principal motivation in themselves. ${ }^{122}$

118. Under the Model Benefit Corp. Legislation, the board of directors of any Benefit Corporation that is publicly traded is required to designate one of its members as the firm's formally recognized "benefit director," who is accordingly responsible for preparing its annual compliance statement. See MODEL BENEFIT CORP. LEGIS. § 302. Notably, there is no corresponding requirement in this regard contained in the Delaware Public Benefit Corporations legislation.

119. Id. $\S \S 302(\mathrm{c})(1), 401(\mathrm{a})(5)$.

120. Id. $\S 302(\mathrm{c})(2)-(3)$.

121. MAYER, FIRM COMMITMENT, supra note 23 , at 153-54.

122. Indeed, this particular understanding of a Benefit Corporation's function has been affirmed by Doug Becker, founder and CEO of the educational services provider, Laureate, which this year is expected to become the first ever formally registered Benefit Corporation (as opposed to Certified B Corp) to undertake a public offering of its shares. See Brad Edmondson, The First Benefit Corporation IPO Is Coming, and That's a Big Deal, TRIPLE PUNDIT (Feb. 4, 2016), http://www.triplepundit.com/2016/02/first-benefit-corporation-ipo-coming-thats-big-deal/\#

[https://perma.cc/75ZK-X5FA]. In the firm's IPO prospectus, Becker explained that, "[w]ith the benefit of a long-term view, we will balance the needs of stockholders with the needs of students, employees and communities in which we operate, and we believe that this approach will deliver the 
In line with the basic private ordering rationality of the general PSV position, the benefit corporation framework is, from an incorporator's perspective, a purely voluntary facility, which-in functional terms - could be said to operate as a state-sanctioned means of "contracting out" of the shareholder primacy norm on a firm-specific basis. However, from a social reformist point of view, this strength is at the same time arguably also the framework's main weakness, especially when viewed alongside the substantive radicalism of the benefit corporation phenomenon in comparison with its orthodox commercial-corporate counterpart.

Indeed, adoption of the benefit corporation model entails not just the express override by incorporators of a shareholder-oriented directors' fiduciary duty (to the extent that it would otherwise exist) in favor of a neutral and multistakeholder-oriented substitute. More fundamentally, it involves the outright rejection of a conventional commercial rationality altogether in favor of a novel, hybrid corporate-value system, whereby "public benefit creation" comes to displace wealth maximization (or even wealth creation) in any accepted economistic sense as the firm's pivotal operational objective. Accordingly, while the optional benefit corporation model is likely to be of considerable instrumental value within certain niche industrial sectors, where the partial pursuit of noncommercial goals is a widely accepted element of responsible business policy (and should therefore be welcomed on this basis), ${ }^{123}$ it is unlikely to be adopted by many firms beyond this relatively peripheral setting, at least in the absence of direct regulatory compulsion to do so. ${ }^{124}$

In any event, even to the extent that the benefit corporation model is adopted in practice, its capacity to negate (insofar as adopting firms are concerned) the influence of the shareholder primacy norm within the public corporations setting is doubtful. As a reformist agenda, the benefit corporation framework is focused principally on recalibrating the fiduciary responsibilities of relevant directors towards the service of predominantly nonshareholder-oriented goals with the associated corporate purpose and disclosure provisions largely reinforcing this

best results for our investors." Id. Since October 1, 2015, Laureate has operated as a registered Delaware Public Benefit Corporation, in addition to its previous status as a Certified B Corp.

123. Indeed, even the White Paper setting out the need and rationale for the Benefit Corporation would appear to accept the likely extraordinary instances of such entities in the context of the forprofit corporate community as a whole. In this regard, it makes express reference to the "sustainable business movement, impact investing and social enterprise sectors" as likely user groups for the new corporate form, citing as specific examples of such "community banks, microfinance institutions, clean-tech or green businesses [and] social venture funds." See CLARK ET AL., WHITE PAPER, supra note 94 , at $1,3-4$.

124. On the (limitations of) the case for direct regulatory compulsion of Benefit Corporation structures and other features of the evolving PSV corporate governance model, see infra Part III. 
central policy objective. ${ }^{125}$ However, as mentioned above, recent academic literature has challenged the notion that directors are actually under any sort of affirmative fiduciary obligation to deferentially serve shareholders' interests, even in an orthodox for-profit corporate setting. ${ }^{126}$ This has, in turn, implicitly called into question the practical value of recalibrating directors' fiduciary duties as a meaningful corporate governance reform measure. ${ }^{127}$

Of course, irrespective of the precise doctrinal substance of directors' fiduciary duties, the mere fact that the law is in practice commonly perceived as imposing on directors an imperative to maximize shareholder wealth is arguably still significant from a behavioral perspective, especially when coupled with litigation fears and other pertinent cultural factors. ${ }^{128}$ Therefore, on an expressive or educative level, the availability of an expressly nonshareholder-oriented alternative to the orthodox for-profit corporate form (in the guise of the benefit corporation) would appear to have some material functional value. ${ }^{129}$

Notwithstanding these considerations, the benefit corporation model is still inherently limited as an effective countermeasure to the influence of the shareholder primacy norm in public corporations. This is because directors' corporate law fiduciary duties - regardless of their actual or perceived content - are arguably a relatively trivial component of the overall corporate governance machinery when it comes to determining the actual working objectives of public corporations in practice. Indeed, it appears that capital market pressures facing boards of directors and senior executives, derived from the background threat of displacement following an outside takeover bid, establish a more continuous and compelling form of managerial accountability to shareholders than that which is likely to emanate from directors' fiduciary duties. ${ }^{130}$

125. On this, see supra notes 104-120 and accompanying text.

126. See supra notes $65-68$ and accompanying text.

127. Cf. infra note 181.

128. See ClARK ET AL., White PAPER, supra note 94 , at 6.

129. On the capacity of law to exert an indirect educative effect by making "statements" as opposed to determining social behavior directly, see generally Cass R. Sunstein, On the Expressive Function of Law, 144 U. PENN. L. REV. 2021 (1996). On the specific context of corporate directorial duty cases, see generally William T. Allen, Jack B. Jacobs \& Leo E. Strine, Jr., Realigning the Standard of Review of Director Due Care with Delaware Public Policy: A Critique of Van Gorkom and its Progeny as a Standard of Review Problem, 96 Nw. U. L. REv. 449 (2002).

130. See Simon Deakin \& Giles Slinger, Hostile Takeovers, Corporate Law, and The Theory of the Firm, 24 J.L. \& Soc. 124, 128 (1997) (noting that "[a]dvocates of an active market for corporate control see it as important partly because of the ineffectiveness of internal corporate control mechanism"). See generally Henry G. Manne, Mergers and the Market for Corporate Control, $73 \mathrm{~J}$. POL. ECON. 110 (1965). 


\section{Broad Judicial Legitimation of Managerial Hostile Takeover Defenses}

Mindful of the inherent limitations of directors' fiduciary duties as a behavioral influence, proponents of the PSV position typically also argue for the broad judicial legitimation of managerial hostile takeover defenses such as poison pills ${ }^{131}$ and staggered boards, pointing to recent Delaware jurisprudence $^{132}$ as supposed evidence that corporate law is actually moving in a general antishareholder-primacy direction. For instance, Mayer supports the use of poison pills and other preclusive takeover defenses as a means of protecting target corporations from the role of short-term financial "arbitrageurs"133 (e.g., hedge funds), who purchase a strategic shareholding in order to effect a transfer of control with a view to making a short-term profit from the resulting share price appreciation. ${ }^{134}$

Mayer argues that the hostile takeover "freezes management of the target firm out of one of the most important decision they have to take - whether or not to remain independent or merge with another firm." As such, a hostile takeover is fundamentally averse to the firm's capacity to operate as a commitment device. ${ }^{135}$ From this perspective, he applauds the Delaware Chancery Court's Airgas $^{136}$ decision in $2010^{137}$ where a public corporation board's dual adoption of a poison pill and staggered board was regarded as a proportionate response (for purposes of the Delaware Unocal test ${ }^{138}$ ) to the threat of short-term arbitrageurs accepting a so-called "low-ball" bid. Accepting such a bid would significantly undervalue the long-term business prospects of the target firm. ${ }^{139}$

131. The term "poison pill" is colloquial shorthand for a so-called "shareholder rights plan," which essentially entails the vesting in shareholders of a contingent right (established under the corporate charter or bylaws, or by way of independent contract) to purchase a corporation's voting stock at a heavily discounted price upon the occurrence of a specified control-related event (e.g., any shareholder reaching a $15 \%$ or $20 \%$ ownership threshold). The intended effect is to threaten the significant dilution of a prospective control-acquirer's holding, effectively forestalling execution of any intended bid. It necessarily follows that, in order to be capable of fulfilling its intended function in this regard, the contingent right granted under the plan to purchase discounted new stock must be denied to the particular shareholder reaching the applicable voting control threshold, otherwise the plan's frustrative effect would be negated. A curious feature of poison pills is that they are never intended to be used directly, such that their power resides purely in their passive threat value. For this reason, they are appropriately described as a "shark-repellent" form of managerial antitakeover mechanism.

132. See, e.g., Air Prod. \& Chemicals, Inc. v. Airgas, Inc., 16 A.3d 48 (Del. Ch. 2011).

133. MAYER, FIRM COMMITMENT, supra note 23, at 109.

134. Id. at $107-11$.

135. Id. at 112 .

136. See generally Airgas, 16 A.3d 48.

137. MAYER, FIRM COMMITMENT, supra note 23, at 109-10.

138. See Unocal Corp. v. Mesa Petroleum Co., 493 A.2d 946, $955-57$ (Del. 1985).

139. See Airgas, 16 A.3d at 103-29. 
However, in terms of contemporary corporate governance practice, it would appear that - at least in the case of larger U.S. listed corporations - the dominant direction of travel in recent years, with respect to control-related issues, has been towards enhanced shareholder power. In particular, an increasing number of firms have succumbed to concerted pressure from investors and proxy advisors to remove antitakeover mechanisms. ${ }^{140}$ Furthermore, as Chancellor Chandler emphasized in Airgas, contrary to popular wisdom, the dual existence of a poison pill and staggered board does not in itself render a corporation "takeover-proof," given the outstanding possibility of a hostile bidder acquiring effective control via the alternative (albeit costly and difficult) avenue of two successive proxy contests if necessary. ${ }^{141}$ Against this background, poison pills and staggered boards can contrarily be said to fulfill their legitimate (shareholder-oriented) purpose of providing a target corporation's board with additional leverage to extract an enhanced tender offer price for shareholders as a precondition to management's future cooperation with the bidder. ${ }^{142}$

\section{Enhanced Use of Dual-Class Voting Structures}

From a corporate controller's perspective, it would appear that the only truly comprehensive way of "locking up" the firm and its internal capital base from unwanted outside overtures is by preventing the dissipation of voting control amongst outside investors entirely, precluding even the residual threat to incumbent management of ouster by way of proxy contest. To this end, some commentators (admittedly including the present author ${ }^{143}$ ) have exhibited support for the enhanced use of dual-class voting structures in public corporations, as an effective means of consolidating corporate voting control in the hands of founding entrepreneurs, families, or other committed long-term investors. ${ }^{144}$

140. Marcel Kahan \& Edward Rock, Embattled CEOs, 88 TEX. L. REv. 987, 1007-09 (2010). 141. See Airgas, 16 A.3d at 115.

142. In this regard, it has been said that, "[t]he length at which Chancellor Chandler's decision [in Airgas] focused on whether the Airgas board had a reasonable basis to conclude that the corporation's stand-alone value would generate returns over time for stockholders that would justify rejecting the premium on the table... demonstrates that he considered the board's sole end to be stockholder welfare[,]" there being "not a hint or suggestion in the case that the directors should consider other constituencies." Hon. Leo E. Strine, Jr., The Dangers of Denial: The Need for a Clear-Eyed Understanding of the Power and Accountability Structure Established by the Delaware General Corporation Law 22 (Univ. of Pa. Law Sch., Inst. of Law \& Econ., Research Paper No. 15-08, 2015), http://ssrn.com/abstract=2576389.

143. See Moore \& Walker-Arnott, supra note 13, at 437-44.

144. See, e.g., MAYER, Firm COMmitment, supra note 23, at 106-07; Stout, Shareholder VAlue MYTH, supra note 59, at 110; Lynn A. Stout, On the Rise of Shareholder Primacy, Signs of Its Fall, and the Return of Managerialism (in the Closet), 36 SEATTLE U. L. REV. 1169, 1182-84 (2013). 
Accordingly, voting shares can be allocated exclusively or, at least on a discriminatory multiple-vote basis, to "inside" (i.e., illiquid non-trading) investors who will consequently enjoy either sole or disproportionate governance influence. ${ }^{145}$ Meanwhile, "outside" (i.e., trading) investors can acquire shares with either no or reduced voting rights on a discounted basis, thereby gaining the benefits of liquidity and cash flow rights but without the additional attribute of control. ${ }^{146}$ In this way, control and commitment can effectively be aligned within the firm in the manner that Mayer's Firm Commitment thesis envisages. ${ }^{147}$

Dual-class voting structures have always been permissible for NASDAQ listed firms, ${ }^{148}$ and NYSE listing rules have since 1986 expressly permitted public corporations to issue dual-class common stock under specific circumstances, ${ }^{149}$ in recognition of the potential practical benefits of these structures in enhancing issuing firms' financing and governance flexibility. ${ }^{150}$ In turn, a number of high-profile businesses including Google, Facebook, LinkedIn, Ford, CBS, Viacom, News Corporation, and Berkshire Hathaway have opted to avail themselves of varying forms of a two-tier voting structure in recent years, in order to provide continuing insulation to controlling "inside" shareholders against potentially destabilizing "outside" investor pressures. ${ }^{151}$ However, in spite of their apparently growing popularity, such arrangements remain the exception rather than the norm within the U.S. public corporation

145. Moore \& Walker-Arnott, supra note 13, at 440.

146. Id.

147. See MAYER, supra note 23, at 209. Contrary to the common concern that such structures entail the unequal treatment of shareholders, Mayer argues that, in fact, "equal treatment of shareholdings is discriminatory between shareholders because those who hold shares for long periods are fundamentally different from those who do not." Id. at 213 (emphasis added).

148. See Tian Wen, You Can't Sell Your Firm and Own it Too: Disallowing Dual-Class Stock Companies From Listing on the Securities Exchanges, 162 U. PA. L. REV. 1496, 1496 (2014).

149. Joel Seligman, Equal Protection in Shareholder Voting Rights: The One Common Share, One Vote Controversy, 54 GEO. WASH. L. REV. 687, 692-93 (1986).

150. In particular, $\S 313.00$ (B) of the NYSE Listed Company Manual specifies that "[t]he Exchange's voting rights policy permits the listing of the voting common stock of a company which also has outstanding non-voting common stock as well as the listing of non-voting common stock," on the preconditions that: (i) "[a]ny class of non-voting common stock that is listed on the Exchange must meet all original listing standards"; (ii) "[t]he rights of the holders of the non-voting common stock should, except for voting rights, be substantially the same as those of the holders of the company's voting common stock"; and (iii) "holders of any listed non-voting common stock must receive all communications, including proxy material, sent generally to the holders of the voting securities."

151. Moore \& Walker-Arnott, supra note 13, at 443; Steven Davidoff Solomon, Shareholder Vote With their Dollars to Have Less of a Say, N.Y. TIMES (Nov. 4, 2015), http://nyti.ms/1iDv2e0. 
community ${ }^{152}$ and are likely to remain so for as long as their adoption remains purely optional on the part of issuing firms. ${ }^{153}$

Moreover, besides the rare possibility of some form of dual-class voting structure being adopted (at least partially) by an existing issuer "in midstream" 154 via a reconstructive secondary offering, it is likely that their adoption will be restricted almost exclusively to newly issuing firms under continuing entrepreneurial or family control. ${ }^{155}$ Therefore, while such mechanisms are a crucial component of the general PSV corporate governance agenda, they are - at least as things presently stand - unlikely to attain a sufficiently strong foothold within established capital market practice to displace the orthodox "one share/one vote" norm in this regard. For the above reasons, it would thus appear that the United States' orthodox, shareholder-oriented corporate governance paradigm looks likely to withstand the current wave of challenges to its hegemony, at least insofar as the principal alternative legal structures remain premised on a purely voluntary and quasi-contractual footing.

\section{SHOUld THE PSV CORPORATE GOVERnANCE MOdEL Be Put ON A FIRMER REGULATORY FOOTING?}

\section{A. The "Market Failure" Rationale for Mandatory Regulatory Imposition of PSV Corporate Governance Principles}

Notwithstanding the unlikelihood of PSV corporate governance principles becoming mainstream norms (at least within the foreseeable future) as a result of micro-level private ordering practices, there may, nonetheless, be cause to consider the more assertive public-regulatory implementation of these mechanisms. In particular, if the common incapacity of entrepreneurs and investors to recognize the purported

152. It has been recorded that, in 2015 , approximately $14 \%$ of US-listed corporations had some form of dual-class share voting structure in place. While this is by all accounts a materially significant figure (especially when compared to the corresponding 2005 figure of just $1 \%$ ), it is - in itself-insufficient to infer the onset of any sort of wholesale shift away from the orthodox one share/one vote policy paradigm. See Solomon, supra note 151 (based on data collated by Dealogic).

153. This is particularly so in light of the recent vocal opposition to dual-class voting structures advanced by some high-profile and influential U.S. capital market actors, including the Council of Institutional Investors and the pension fund CalPERS. See Solomon, supra note 151; Council of Institutional Investors, Dual-Class Stock, http://www.cii.org/dualclass_stock; Ross Kerber, US Investor Group Urges Halt to Dual-Class Structures in IPOs, REUTERS (Mar. 23, 2016), http://reut.rs/1UFNKCB.

154. This term - attributable to Professor Lucian Bebchuk — denotes (the extraordinary case of) constitutional amendments implemented by a firm during its existing life cycle as a publicly listed corporation, as opposed to (the standard case of) such provision being made at the earlier, initial public offering stage. See Lucian Ayre Bebchuk, Limiting Contractual Freedom in Corporate Law: The Desirable Constraints on Charter Amendments, 102 HARV. L. REV. 1820, 1822 (1989).

155. Moore \& Walker-Arnott, supra note 13, at 440. 
economic advantages of the PSV corporate governance platform (at least relative to the shareholder primacy/equality orthodoxy) represents an incidence of market failure, then it follows that recourse to firmer methods of regulatory intervention in this regard is arguably justified in the public interest. ${ }^{156}$

On the (presently assumed) dual premise that: (i) the purported "lock-in" benefits of the PSV corporate governance platform create long-term economic benefits from which a corporation's stakeholders (including its shareholders) as a whole generally stand to benefit; but (ii) due to a combination of informational limitations and systematic irrationality, entrepreneurs and/or investors will likely not avail themselves of the key features of this model in practice; it arguably follows that the direct regulatory compulsion of those structures is normatively defensible. ${ }^{157}$ The "market failure" case for the mandatory regulatory imposition of PSV corporate governance principles thus rests on a fundamentally paternalistic basis. That is to say, public policymakers, via appropriately targeted interventions in private ordering, are arguably capable of providing what corporate contractors "would have wanted" as determined by reference to a notionally ideal hypothetical bargaining scenario. ${ }^{158}$

While this rationale for the mandatory regulatory imposition of PSV corporate governance principles may hold a certain intuitive appeal to those of reformist zeal, it is nonetheless problematic. As is well known, the principal disadvantage of legally compelling any social-institutional structure (including a particular corporate governance model) is the fact that it admits no room for flexibility or deviation from the standard norms, such that occasional reasonable exceptions cannot be accommodated. ${ }^{159}$ Indeed, notwithstanding the purported comparative advantages of the PSV corporate governance model, it is conceivable that in many firms pressing managerial accountability (i.e., "agency cost") concerns will still justify

156. On the "market failure" rationale for mandatory corporate law rules generally, see MOORE, CORPORATE GOVERNANCE, supra note 18, at 238-47.

157. See id. at 240. In this regard, Jeffrey Gordon argues that "it is a mistake to assume that full contractual freedom in corporate law would necessarily lead to private wealth maximization," but rather that " $[t]$ he existence of some mandatory rules may lead to better contracts." Jeffrey N. Gordon, The Mandatory Structure of Corporate Law, 89 COLUM. L. REV. 1549, 1554 (1989).

158. See Lucian Arye Bebchuk, The Debate on Contractual Freedom in Corporate Law, 89 Colum. L. Rev. 1395, 1410-11 (1989); Bernard S. Black, Is Corporate Law Trivial?: A Political and Economic Analysis, 84 Nw. U. L. REV. 542, 551-52 (1990); Marc T. Moore, Private Ordering and Public Policy: The Paradoxical Foundations of Corporate Contractarianism, 34 OXFORD J. LEGAL STUD. 693, 710-14 (2014); David Charny, Hypothetical Bargains: The Normative Structure of Contract Interpretation, 89 MicH. L. REV. 1815, 1815-16 (1991).

159. On the purported functional benefits of a flexible "enabling" (as opposed to mandatory regulatory) approach to the design of corporate law rules generally, see EASTERBROOK \& FISCHEL, CORPORATE LAW, supra note 2, ch. 1; MOORE, CORPORATE GOVERNANCE, supra note 18, at 101-06. 
entrepreneurs or investors rationally opting for a traditional shareholder-oriented governance framework, notwithstanding the concomitant loss of long-term capital commitment that this arrangement potentially entails. ${ }^{160}$ Largely for this reason, regulatory implementation of any particular feature(s) of the PSV corporate governance model on a mandatory basis (whether at a federal, state, or stock exchange level) is most likely inadvisable, notwithstanding the purported substantive merits of the relevant model itself. ${ }^{161}$

\section{B. The (Neglected) Social-Distributive Dimension of Corporate Equity Markets}

Additionally, there is a more general cause for concern about the growing appetite for alternatives to the traditional shareholder-oriented corporate governance paradigm, which should provide further grounds for caution when it comes to evaluating the merits of any future regulatory initiatives in this direction. While critics of the shareholder primacy orthodoxy are entirely justified in highlighting the various respects in which excessive shareholder influence can be potentially detrimental to long-term industrial planning and capital formation, this presents only one part of the overall picture.

Indeed, a common limitation of the abovementioned critiques of the shareholder-oriented corporation is its tendency to focus exclusively on the productive side of corporate capital markets: that is to say, in terms of what investors - via the medium of capital (and especially equity) markets - contribute to business corporations in terms of prospective productive resources. However, arguably, at least as important from a social perspective is the converse distributive side of corporate capital markets; in other words, what business corporations (via capital markets) contribute to investors in the form of actual or anticipated private income streams. ${ }^{162}$ From this alternative perspective, the principal social utility of capital markets inheres in its capacity to enable the private (i.e., non-state-administered) generation and distribution of non-occupational income streams to citizens (especially private pension holders) via returns

160. Indeed, Mayer himself effectively makes this very point, stating that "[t]he success of the corporation depends on its ability to balance its powers of commitment and control," such that "[i]n some cases a high degree of commitment to many parties is required; [whereas] in others, being able to exercise external control with no commitments is essential." See MAYER, FIRM COMMITMENT, supra note 23, at 230, 234.

161. On Mayer's general preference for flexible/enabling as opposed to mandatory/regulatory methods for implementing effective firm commitment mechanisms in practice, see supra notes $82-90$ and accompanying text.

162. On this generally, see Martin Gelter, The Pension System and the Rise of Shareholder Primacy, 43 Seton Hall L. Rev. 909, 911 (2013). 
on direct or indirect corporate securities holdings. Moreover, equity markets in particular have special relevance in this regard, insofar as no other type of security is generally capable of yielding a sufficient ongoing rate of return to meet the current and future income expectations of pension fund beneficiaries. ${ }^{163}$

Appreciation of the social-distributive dimension of public equity markets and the ensuing knock-on effect of these demands on prevailing corporate governance norms is by no means novel. Indeed, writing as long ago as 1932 (in the context of a debate about the merits of facilitating voluntary corporate social responsiveness ${ }^{164}$ ), Adolf Berle recognized that "not less than half of the population of the country"165 at the time was directly dependent on corporate securities holdings as an essential means of non-occupational income provision, "to say nothing of indirect results." 166 Berle ominously warned that "when the fund and income stream upon which this group rely are irresponsibly dealt with, a large portion of the group merely devolves on the community; and there is presented a staggering bill for relief, old age pensions, sickness-aid, and the like." ${ }^{\prime 67}$ For this reason, Berle believed that any radical proposal to replace shareholder primacy with a more socially oriented alternative corporate governance paradigm necessarily confronts the corresponding task of "present[ing] a system (none has been presented) of law or government, or both, by which responsibility for control of national wealth and income is so apportioned and enforced that the community as a whole, or at least the great bulk of it, is properly taken care of."168

Moreover, major demographic shifts - on both a domestic and global level-in the intervening eight decades since Berle and Dodd's fabled exchange have significantly magnified the gravity of the social welfare

163. Id. at 928. Indeed, it has been remarked that "for a growing group of investors, participation in the stock market can no longer be thought of as a voluntary endeavor for those with discretionary or extra funds," but rather "has become a default form of retirement savings, a personally important task that is crucial to individual and social financial stability." Anne Tucker, The Citizen Shareholder: Modernizing the Agency Paradigm to Reflect How and Why a Majority of Americans Invest in the Market, 35 SEATTLE U. L. REV. 1299, 1303 (2012). Tucker notes that a key driving factor in this regard is the institution of automatic employee enrollment in employer-sponsored 401(k) plans. See Tucker, supra at 1315.

164. See generally E. Merrick Dodd, Jr., For Whom Are Corporate Managers Trustees?, 45 Harv. L. Rev. 1145 (1932); A. A. Berle, Jr., For Whom Corporate Managers Are Trustees: A Note, 45 HARV. L. REV. 1365 (1932); William W. Bratton \& Michael L. Wachter, Shareholder Primacy's Corporatist Origins: Adolf Berle and The Modern Corporation, 34 J. CORP. L. 99 (2008); C.A. Harwell Wells, The Cycles of Corporate Social Responsibility: An Historical Retrospective for the Twenty-first Century, 51 KAN. L. REV. 77 (2002).

165. Berle, supra note 164, at 1368.

166. Id.

167. Id.

168. Id. 
concerns that Berle identified back in $1932 .{ }^{169}$ Globally, it has been recorded that "[s]ince World War II, life expectancy at birth has risen from around age forty-five to sixty-five - a greater gain over the past fifty years than over the previous 5,000"; whereas, "[i]n the developed countries, it has risen from around age sixty-five to between seventy-five and eighty." 170 In this regard, a recent United Nations report warns that "[b]etween 2015 and 2030, the number of people in the world aged 60 years or over is projected to grow by $56 \%$, from 901 million to 1.4 billion, and by $2050 \ldots$ to more than double its size in 2015, reaching nearly 2.1 billion." "171

Meanwhile, in the specific context of the United States, the portion of the national population aged sixty or over is anticipated to increase from a current figure of approximately 66.5 million (as of 2015) to 93 million by 2030 , and to more than 108 million by $2050 .{ }^{172}$ Given the unlikelihood of a parallel rise in fertility rates over the same time period, the implication is that a rapidly aging population ${ }^{173}$ - together with the significant social welfare challenges that this necessarily entails ${ }^{174}$ - are now considerably greater concerns for public policymakers than they were in Berle's lifetime. As will be explained below, this arguably stands true nowhere more so than in the overlapping fields of corporate governance and capital markets.

169. Indeed, it has been estimated that over 92 million Americans, constituting approximately $50 \%-54 \%$ of U.S. households, are indirectly invested in the stock market by way of mutual funds, with the great majority of such indirect investors doing so for future retirement purposes. See Tucker, supra note 163, at 1308, 1312-14; Anne Tucker, Retirement Revolution: Unmitigated Risks in the Defined Contribution Society, 51 Hous. L. Rev. 153, 159 (2013).

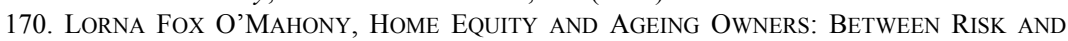
REgulation 5, n.27 (2012) (quoting Richard JaCKSON, THE GLOBAL RETIREMENT CRISIS: THE Threat TO WORLD STABILITY AND WHAT TO DO ABOUT IT 10 (2002), https://csisprod.s3.amazonaws.com/s3fs-public/legacy_files/files/media/csis/pubs/global_retirement.pdf [https://perma.cc/3SA9-85SY].

171. U.N. DEP'T OF ECON. \& SOC. AfFairs, POPUlation Div., World Population AgEing 2015, U.N. Doc. ST/ESA/SER.A/390, at 2 (2015), http://www.un.org/en/development/desa/ population/publications/pdf/ageing/WPA2015_Report.pdf [https://perma.cc/M93K-WJQ7].

172. Id. at 126 .

173. According to the U.N.'s Population Division, “[p]opulation ageing is an inevitable consequence of the demographic transition [that] began first in Europe and Northern America, where fertility reductions took place over the past two centuries, contributing to their relatively aged population age structures today." Id. at 57.

174. See generally William A. Jackson, The Political EConomy of Population Ageing (1998); Paul Wallace, Agequake: Riding the Demographic Rollercoaster Shaking Business, FinANCE AND OUR WORLD (1999); Anthea Tinker, The Social Implications of an Ageing Population, 123 Mechanisms Ageing \& Dev. 729 (2002). 


\section{The Shareholder Primacy Norm as a Socially Essential Income-Stabilization Mechanism}

At the root of the social dilemma to which Berle was alluding is the basic structure of a private pensions system linked to capital market returns, and - in particular - the need for some agent willing to play a macro level risk-underwriting role therein. That is to say, there must be some public or private constituency prepared to undertake the contingent cost of absorbing any negative deficit arising between: (i) the aggregate value of "active" contributions to the pensions system by prospective future claimants (i.e., current workers); minus (ii) the aggregate value of current claims against the system by "passive" members (i.e., pensioners). In a predominantly public (i.e., state-administered) pensions system, any such deficit will ordinarily be borne (in the last place) by the relevant national government itself, so that the taxpayer in effect plays the principal risk-underwriting role. ${ }^{175}$ In a predominantly private (i.e., non-state-administered) pensions system, on the other hand, the main risk-underwriting role in this regard is typically played by non-state agents, whether employer firms or-as is increasingly typical today-individual worker-savers. ${ }^{176}$

In the so-called "defined benefit" private pensions system that was prevalent in this country for much of the previous century, any systemic deficit was customarily borne by employer firms, insofar as beneficiaries' entitlements were guaranteed at a contractually pre-determined level (e.g., as a fixed percentage of the beneficiary's final pre-retirement salary). ${ }^{177}$ However, in the "defined contribution" private pensions system that generally prevails in the United States today, it is instead the general (or at least middle-class) public as worker-savers who become principal risk-underwriters in the above sense. This is because the inherent open-endedness of beneficiaries' ultimate entitlements from their respective schemes, which typically include no guaranteed level of postemployment income, in effect renders worker-savers' future income-generating capacity contingent in large part on the continuing (variable) rates of return on equity investments made on their behalf. ${ }^{178}$

Against the above background, the practical capacity of non-state agents - and, in particular, worker-savers - to underwrite the private

175. Gelter, supra note 162, at 965.

176. See id. at $941-44$.

177. Id. at 941.

178. Id. at 943 . The term "defined contribution society" has been used to refer to the contemporary environment "where increasingly the average worker saves for retirement by investing in private securities markets and becoming a shareholder." See Tucker, supra note 169, at 157. The term itself is originally attributable to Edward A. Zelinsky, The Defined Contribution Paradigm, 114 YALE L.J. 451, 454 (2004). 
pensions system is dependent on the existence of a supportive corporate governance system, whereby long-term returns on financial (and especially equity) capital are proximately stabilized. ${ }^{179}$ Somewhat paradoxically, this in turn necessitates an underpinning legal framework whereby the collective interests of shareholders are systematically given precedence over the countervailing interests of other stakeholders (and especially employees) in the event of conflict, particularly with respect to decisions concerning the ongoing allocation of residual corporate earnings or cash flows. ${ }^{180}$ It follows that the legally underpinned principle of shareholder primacy — in the limited yet meaningful form in which it exists within orthodox corporate law today ${ }^{181}$ —remains functionally necessary

179. On the general collective preference of institutional investors and analysts for ongoing stability and predictability in investee firms' periodic earnings profiles, along with corresponding managerial strategies for "managing" corporate earnings according to the market's expectations in this regard, see Joseph Fuller \& Michael C. Jensen, Just Say No to Wall Street: Putting a Stop to the Earnings Game, 14 J. ApPlied CORP. FIN. 41, 42 (2002); David Millon, Why is Corporate Management Obsessed with Quarterly Earnings and What Should be Done About It?, 70 GEO. WASH. L. REV. 890, 897-900 (2002); Moore \& Walker-Arnott, supra note 13, at 423-32.

180. Indeed, it is commonly acknowledged that dividends and stock buybacks-which were used strategically by management - constitute important earnings management practices geared to stabilizing perceived levels of shareholder return. In this regard, the market's typical primary demand of an investee firm is that it generates a consistently positive rate of periodic earnings-per-share (or "EPS") growth, preferably coupled with a correspondingly steady rise in its declared rate of dividend. From the viewpoint of investors, steady EPS and dividend growth are desirable corporate attributes for two main reasons. First, continuing dual EPS and dividend growth ensures ongoing increases in total shareholder return, whether in realized (that is, dividend) or realizable (consequent stock price appreciation) form. And, second, the same qualities are (on a superficial level at least) indicative of management's capacity to forestall potential turbulence in the firm's trading environment, and thus are implicit signals of corporate stability and reliability. Meanwhile, stock buybacks enable management to artificially enhance a corporation's periodic EPS from time to time, thereby further facilitating the abovementioned income stabilization process. In particular, strategic stock buybacks have the intended effect of reducing the denominator (that is, number of shares) of the firm's earnings-per-share ratio, so that each share is notionally representative of a greater proportion of total shareholder wealth created over the relevant time period. At the same time, stock buybacks enable management to directly increase the periodic level of total shareholder return via direct distribution of the corporation's free cash flow, but without bringing about a corresponding rise in its current rate of dividend. Consequently, management is able to avoid enhancing general market expectations as to the trajectory of future annual dividend rate increases. The earnings management function of strategic stock buybacks can be especially valuable for a firm's management in the absence of manifest evidence of significant activity or progress on a business-operational level, insofar as it forestalls potential market concerns about apparent wastage of the corporation's unused free cash flow. See John F. Weston et AL., TAKeOVERs, Restructuring, \& Corporate GovernanCe 537 (3d ed. 2001); Michel Aglietta, Shareholder Value and Corporate Governance: Some Tricky Questions, 29 ECON. \& SoC'Y 146, 151 (2000); Joel F. Houston et al., To Guide or Not to Guide? Causes and Consequences of Stopping Quarterly Earnings Guidance, 27 CONTEMP. ACC. RES. 143, 144 (2010); Moore \& Walker-Arnott, supra note 13, at 428-29.

181. Granted, it is indeed - to quote Lynn Stout—a "myth" to assert that corporate law imposes any direct or express duty on directors to maximize shareholder wealth as such. See STOUT, SHAREHOLDER VALUE MYTH, supra note 59, at 25. However, to infer from this the broader proposition that corporate law thus affords $n o$ lexical priority to the interests of shareholders over other 
for ensuring that, in the last place, directors' (and, indirectly, managers') continuing right to hold office is formally contingent on shareholders' exclusive (revocable) license. ${ }^{182}$

From a distributive or supply-side perspective, one of the key implications of the shareholder primacy norm - as understood in the above sense-is that it consequently pressures management to ensure that any product market or other environmental "shocks" to the firm's business are borne as much as possible by non-shareholder constituents, and especially by labor. This in turn facilitates the proximate stabilization of income streams accruing to worker-savers in their quasi-shareholder capacity as private pension fund beneficiaries, thereby making it possible for worker-savers to undertake a collective risk-underwriting function with respect to the significant private (i.e., non-state-supported) component of

stakeholders is equally fallacious. As Delaware Supreme Court Chief Justice Leo Strine has recently stressed, contrary to popular academic assertion shareholder primacy remains a pivotal principle of Delaware jurisprudence on corporate law, particularly in the realm of directors' fiduciary duties. See Strine, supra note 142 , at 17-18. Accordingly, while "[t]he fiduciary duty to manage a corporate enterprise includes the selection of a time frame for achievement of corporate goals," such that directors are expressly "not obliged to abandon a deliberately conceived corporate plan for a shortterm shareholder profit" (per Horsey, J., in Paramount Commc'ns., Inc. v. Time Inc., 571 A.2d 1140, 1154 (Del. 1989)); this does not displace shareholder wealth as the ultimate fiduciary litmus test for determining the propriety of directors' discretionary decisions on business policy. Rather, as Chief Justice Strine emphasizes, both classical and recent case law clearly establishes that "if a fiduciary admits that he is treating an interest other than stockholder wealth as an end in itself, rather than an instrument to stockholder wealth, he is committing a breach of fiduciary duty." See Strine, id. at 20. This fundamental tenet of Delaware corporate law was most recently reaffirmed in the 2010 case of eBay Domestic Holdings, Inc. v. Newmark, 16 A.3d 1 (Del. Ch. 2010), where Chancellor Chandler emphasized that "[t]he [orthodox] corporate form... is not an appropriate vehicle for purely philanthropic ends" and consequently that "I cannot accept as valid... a corporate policy that specifically, clearly, and admittedly seeks not to maximize the economic value of a for-profit Delaware corporation for the benefit of its stockholders." 16 A.3d at 34. The same essential point is put succinctly by Professor Stephen Bainbridge, who posits that "despite occasional academic arguments to the contrary, the shareholder wealth maximization norm expounded by these courts indisputably is the law in the United States." See BAINBRIDGe, The New CORPORATE GOVERnANCE, supra note 2, at 53. The author is further grateful to Dr. Robert Austin for illuminating recent discussions in relation to this issue, and in particular for sharing his excellent (currently unpublished) paper, Do the Directors of a Business Corporation (Still) Have a Duty to Maximise Shareholder Wealth (2016), which he presented at the University of Oxford Faculty of Law in May 2016.

182. Specifically, common stockholders' exclusive collective power of (re)appointment over directors, as undergirded by their residual fiduciary entitlement described above, in effect activates the background disciplinary mechanism of the market for corporate control, whose operation is dependent on the technical possibility of outright managerial displacement via a successful proxy contest. See BAINBRIDGe, THE New CORPORATE GOVERnANCE, supra note 2, at 55; EASTERBROOK \& Fischel, CORPORATE LAW supra note 2, at 67 (explaining that while voter-shareholders in practice "delegate extensively to managers and almost always endorse their decisions[,] . . . this acquiescence should not obscure the fact that managers exercise authority at the sufferance of investors"). 
the pension system. ${ }^{183}$ However, on a macro level, such relative income-stability for worker-savers in their long-term "saver" identity is necessarily wrought at the cost of increased income instability in their immediate "worker" guise; given that the current income-generating capacity of private sector employees is consequently exposed to the impact of occasional product market and other environmental shocks to a correspondingly greater extent. ${ }^{184}$

\section{Shareholder Primacy as the Effective Social "Price" of Sustaining a Capital-Market-Based Pensions System}

In the above way, the shareholder primacy principle constitutes part of the social contract (or proverbial "Faustian Pact") to which worker-savers can be said implicitly to assent in order to sustain a system of non-occupational income provision outside of direct state control. Accordingly, the risk-adjusted present value of worker-savers' human capital is reduced in order to increase the risk-adjusted present value of their financial (and especially equity) capital. From this point of view, shareholder primacy-for all its alleged faults - can ultimately be regarded as the collective social "price" that citizens (as worker-savers) pay in order to sustain a pensions system that has the capacity to deliver levels of social income (largely via returns on institutional equity holdings), which would almost certainly be economically and politically infeasible to underwrite via state (i.e., taxpayer) provision alone.

Moreover, recent statistics show that the general public's relative dependence on direct or indirect corporate equity holdings as a relative source of non-occupational wealth gains is increasing yet further today. ${ }^{185}$ In the United States, this would appear to be especially true for the younger (under thirty-five) generation, for whom housing wealth in particular has become a decreasing component of aggregate household wealth over

183. On the economic risk-bearing function of defined contribution pension-beneficiaries, and consequent importance of macro-level stock market stability to worker-savers' collective financial security, see Tucker, supra note 163, at 1315-20.

184. On the purported correlation between: (i) the amount of pension wealth in (employee-underwritten) defined contribution occupational pension plans, and (ii) the general social attractiveness of shareholder-oriented corporate governance policies relative to countervailing labor-oriented measures, see Gelter, supra note 162, at 946-47.

185. 2012 Economic Census data demonstrates that the percentage of aggregate U.S. household wealth (both occupational and non-occupational) held in the form of shares, mutual funds and/or stock-market-based savings/retirement plans increased more than five-fold over the past three decades, from a figure of $9 \%$ in 1984 to $46 \%$ in 2011 ; at the same time, the corresponding percentage of total household wealth held in the form of home equity substantially decreased over the same period, from $41 \%$ in 1984 to $25 \%$ in 2011. See Alfred GotTsChalcK ET AL., Household Wealth IN THE U.S.: 2000 TO 2011, U.S. CENSUS BUREAU (2012), 2-3, 6, http://www.census.gov/people/ wealth/files/Wealth\%20Highlights\%202011.pdf [https://perma.cc/6WLK-F2YM]. 
recent years. ${ }^{186}$ This seemingly further enhances the relative social significance of corporate equity markets as a social wealth-generating mechanism, together with the corresponding systemic importance of the shareholder primacy norm in U.S. corporate governance. ${ }^{187}$

The key normative implication of the above findings is that any truly meaningful attempt to reform the shareholder primacy orthodoxy in U.S. corporate governance-for instance, in favor of a more directly stakeholder-oriented Post-Shareholder-Value paradigm-must contend with the accompanying need for a comprehensive re-writing of the latent social contract $^{188}$ on which the country's current

186. Between 1984 and 2011, the percentage of aggregate wealth of households with householders under 35 years of age held in the form of home equity decreased from $46 \%$ in 1984 to $21 \%$ in 2011 . See id. at 3,6 .

187. Of course, it could be said that the aggregate focus of the above figures obscures latent wealth-distributional factors which call into question the claim that corporate equity-holding in the United States represents a "democratic" phenomenon in any meaningful sense of the word. In this regard, Bratton and Wachter have observed that "even as shareholding has diffused downward to lower income individuals, the shareholders' overall socioeconomic status has remained largely unchanged," such that even today "the shareholder class is not meaningfully middle class and retains elite characteristics"; in particular, the authors point to the fact that, between 1983 and 2007, the percentage of all U.S.-listed stock held by the wealthiest $10 \%$ of the population decreased only incrementally from $89 \%$ to $81 \%$, demonstrating that "there is nothing inherently democratic or progressive about the shareholder interest in corporate politics." See William W. Bratton \& Michael L. Wachter, Shareholders and Social Welfare, 36 SEATTLE U. L. REV. 489, 490-91, 518 (2013). Drawing on a comparable (slightly earlier) body of data from both the U.S. and U.K., Ireland has drawn the similar conclusion that "[a]lthough share ownership has become more widely spread,... it remains very heavily concentrated with the result that shareholder primacy is in reality the primacy of a small privileged elite." See Paddy Ireland, Shareholder Primacy and the Distribution of Wealth, 68 MoD. L. REV. 49, 49 (2005). While I do not contest the significance of such manifest inequality in conditioning the general social legitimacy of the shareholder-oriented U.S. corporate governance model, it remains the case that in absolute (if not relative) social terms, stock-market-based wealth is still a highly material source of non-occupational income for a sizeable proportion of American households. Therefore, on a functional or systemic (if not normative or ideological) level at least, its basic socialdistributive utility is arguably undiminished, notwithstanding the undisputable fact that some strands of the national socio-economic spectrum stand to benefit considerably more than others with respect to their relative share of the resultant spoils.

188. Of course, irrespective of the continuing social utility of the United States' capital-marketbased pension system in actual functional terms, it is arguable that the long-term social (and, in turn, political) sustainability of the shareholder-oriented corporate governance model that undergirds it is ultimately contingent on the credibility of the continuing public perception that it exists to benefit the population at large (or at least in substantial part) in some material way, as opposed to just serving a relatively privileged or "elite" financial-managerial minority. See JOHN W. CIOFFI, PUBLIC LAW AND Private Power: Corporate Governance ReForm in the Age of Financial Capitalism 11 (2010). However, at least as things presently stand, it would appear that the so-called "shareholder class" remains a sufficiently salient and (at least notionally) representative political interest grouping - particularly on the center-left of the U.S. political spectrum - to buttress the continuation of a general public policy agenda (at least at the federal level) geared to preserving the shareholder-oriented corporate governance paradigm. See Gelter, supra note 162, at 949; William W. Bratton \& Michael L. Wachter, The Political Economy of Fraud on the Market, 160 U. PA. L. REV. 69, 81 (2011). Hence the abovementioned "social contract" arguably remains valid today, notwithstanding growing public and political disquiet over recent years about the perceived unfair 
capital-market-based welfare system is predicated. ${ }^{189}$ It is submitted that, absent this necessary broader inquiry into the significant systemic overlaps between corporate governance and the prevailing national social welfare framework, reformers should err on the side of caution. Hence, while ad hoc voluntary adoption of PSV corporate governance structures by individual firms should by all means be tolerated (and indeed encouraged), any civil society pressures for more robust regulatory moves in this general direction should be resisted by public policymakers for the time being.

\section{CONCLUSION}

To return to the discussion at the beginning of this Article: despite various attempts to identify the "true" source of the public corporation's institutional uniqueness, it is arguable that the most remarkable of all its structural features remains largely elided by academic observers. That is the public corporation's somewhat peculiar dual identity as both: (i) a productive, and (ii) a social-distributive mechanism.

Accordingly, public corporations are not only the predominant organizational vehicle for conducting large-scale industrial production projects over indefinite time horizons, as academic proponents of the Post-Shareholder-Value position have vigorously emphasized. Of comparable importance and ingenuity is the fact that - in the United States at least-public corporations are also a necessary structural means of enabling the residual income streams accruing from successful industrial projects to fund the provision of socially essential financial services, via the medium of public capital (and especially equity) markets. Unfortunately, these two dimensions of the public corporation are not always mutually compatible. Rather, it would seem that more often than not they are prone to antagonize, rather than complement, one another. This is especially so when it comes to the periodically vexing managerial question of whether a firm's residual earnings should be committed internally to the sustenance and development of the productive corporate enterprise itself, or else distributed externally to shareholders in the form of either enhanced dividends or stock buybacks. ${ }^{190}$

It is submitted that the evolving PSV corporate governance paradigm - as manifested on both an intellectual and policy level today-focuses exclusively on the former of those dimensions at the

distributional consequences of the prevailing corporate governance (and, moreover, general neo-liberal politico-economic) policy orthodoxy.

189. On the potential public policy alternative of expanding the taxpayer-funded Social Security system to cover the projected income needs of future retirees, see Paul Krugman, Expanding Social Security, N.Y. TIMES (Nov. 21, 2013), http://nyti.ms/1DxeCYn.

190. See supra note 180 and accompanying text. 
expense of the latter. Granted, the theoretical insights and practical reform measures that this movement has generated-and, in particular, the proliferation of benefit corporations and legitimization of dual-class voting schemes - deserve commendation as highly beneficial developments, at least when viewed from this particular (productive) perspective. For this reason alone, it is submitted that the continuing voluntary adoption of such structures by individual firms should be both permitted and-moreover-actively encouraged by relevant laws. However, encouragement is a very different thing from compulsion, and it does not follow from the peripheral successes of the PSV movement to date that the direct regulatory curtailment of any aspect(s) of the orthodox shareholder-oriented corporate governance framework is consequently merited. That is, at least without public policymakers being receptive to the potentially significant indirect social ramifications of any such course of action.

The somewhat uncomfortable truth for many observers is that, for better or worse, the American system of shareholder capitalism, and its pivotal corporate governance principle of shareholder primacy, are ultimately products of our own collective (albeit unintentional) civic design. And, until academics and policymakers are capable of coordinating their respective energies in the direction of somehow alleviating U.S. worker-savers' significant dependence on corporate equity as a source of non-occupational wealth gains, ${ }^{191}$ they would be well advised to heed Professor Berle's warning that "[n]othing is accomplished, either as a matter of law or of economics, merely by saying that the claim of this group [i.e., shareholders] ought not to be "emphasized." 192 In the meanwhile, the shareholder-oriented corporation-despite its many purported evils - is likely to remain a socially indispensable phenomenon. To those who rue this prospect, it might be retorted, "better the devil you know than the devil you don't."

191. As Gelter argues, "[s]keptics of shareholder primacy must rethink their agenda and address U.S. dependence on equity investment. Otherwise, attempts to challenge the dominant model will be futile." Gelter, supra note 162, at 970.

192. Berle, supra note 164, at 1368. 